\title{
Institutional Ownership and Corporate Tax Avoidance: New Evidence
}

\section{Citation}

Khan, Mozaffar N., Suraj Srinivasan, and Liang Tan. "Institutional Ownership and Corporate Tax Avoidance: New Evidence." Accounting Review 92, no. 2 (March 2017): 101-122.

\section{Published Version}

http://dx.doi.org/10.2308/accr-51529

\section{Permanent link}

http://nrs.harvard.edu/urn-3:HUL.InstRepos:30203358

\section{Terms of Use}

This article was downloaded from Harvard University's DASH repository, and is made available under the terms and conditions applicable to Open Access Policy Articles, as set forth at http:// nrs.harvard.edu/urn-3:HUL.InstRepos:dash.current.terms-of-use\#OAP

\section{Share Your Story}

The Harvard community has made this article openly available.

Please share how this access benefits you. Submit a story.

Accessibility 


\title{
Institutional Ownership and Corporate Tax Avoidance: New Evidence
}

\author{
Mozaffar Khan \\ Harvard University and University of Minnesota \\ Suraj Srinivasan \\ Harvard University \\ Liang Tan \\ George Washington University
}

Khan and Srinivasan are at Harvard Business School, Soldiers Field, Boston, MA 02163. Email mkhan@hbs.edu and ssrinivasan@hbs.edu, respectively. Tan is at The George Washington University School of Business, $2201 \mathrm{G} \mathrm{St}$ NW, Washington, DC 20052. Email liangtan@gwu.edu. We thank the editor (Edward Maydew) and the reviewers for very helpful comments. 


\title{
Institutional Ownership and Corporate Tax Avoidance: New Evidence
}

\begin{abstract}
We provide new evidence on the agency theory of corporate tax avoidance (Slemrod 2004; Crocker and Slemrod 2005; Chen and Chu 2005) by showing that increases in institutional ownership are associated with increases in tax avoidance. Using the Russell index reconstitution setting to isolate exogenous shocks to institutional ownership, and a regression discontinuity design that facilitates sharper identification of treatment effects, we find a significant and discontinuous increase in tax avoidance following Russell 2000 inclusion. The tax avoidance involves the use of tax shelters, and immediate benefits include higher profit margins and likelihood of meeting or beating analyst expectations. Collectively the results shed light on the effect of increased ownership concentration on tax avoidance.
\end{abstract}

Keywords: Tax avoidance, Agency costs, Institutional ownership 


\section{INTRODUCTION}

Corporate income taxes represent a significant expense to shareholders. Yet tax avoidance, defined as the reduction of explicit taxes (Hanlon and Heitzman 2010), appears underexploited by firms (Weisbach 2002) and exhibits substantial cross-sectional variation (Dyreng, Hanlon, and Maydew 2008). ${ }^{1}$ These empirical patterns point to variation in benefits and costs and lead Shackelford and Shevlin (2001) to call for further research into the determinants of tax avoidance. Hanlon and Heitzman (2010) renew this call and, in particular, suggest the promise of a younger strand of the literature that explores the role of agency frictions in explaining variation in tax avoidance (Slemrod 2004; Chen and Chu 2005; Crocker and Slemrod 2005). Pursuing this perspective, recent papers have examined the role of ownership structure in the form of family ownership of public firms, dual-class shares, hedge fund ownership, and private equity backing of private firms (Chen, Chen, Cheng, and Shevlin 2010; Cheng, Huang, Li, and Stanfield 2012; Badertscher, Katz, and Rego 2013; McGuire, Wang, and Wilson 2014). In this paper we examine the role of quasi-indexer institutional investors (Bushee 1998, 2001) in explaining variation in tax avoidance.

Shareholders are expected to weigh the benefits of tax avoidance against the costs of potential enforcement, penalty, and reputation loss to the firm if the strategy is flagged by tax authorities (Hanlon and Heitzman 2010). Firms' managers have significant individual effects on tax avoidance (Dyreng, Hanlon, and Maydew 2010), and are expected to weigh the private benefits from higher firm returns against the private costs in the event of enforcement action by tax authorities. These private managerial costs, which include potential job and reputation loss and other private penalties, are likely significant. If shareholders' assessment of the cost-benefit

\footnotetext{
${ }^{1}$ As in the prior literature referenced here, we use "tax avoidance" as a neutral term to represent a spectrum of strategies that reduce explicit taxes.
} 
tradeoff of tax avoidance is different from managers' private assessment of this tradeoff, then changes in ownership structure likely hold explanatory power for corporate tax avoidance.

Following the Bushee $(1998,2001)$ classification of institutional investors, we refer to quasi-indexers as investors with passive and diversified holdings, transient investors as those with short-run holdings and active trading, and dedicated investors as those with passive and concentrated holdings. Our hypotheses and tests relate primarily to quasi-indexers. Institutional investors, including quasi-indexers, mitigate the collective-action problem among shareholders and are well placed to monitor and influence managerial action. Quasi-indexers' investment mandate limits their flexibility to "vote with their feet," and thereby provides an incentive for them to influence managerial actions (Monks and Minow 1995). ${ }^{2}$ This influence can be exercised through institutional investors" "say on pay," and through support for other activist shareholders (e.g., hedge funds as in Cheng et al. 2012) who promote a particular action.

Quasi-indexers need not explicitly and specifically promote tax avoidance for two reasons. First, their interest is in increasing shareholders' share of earnings (or after-tax income), and therefore any combination of feasible cost-reduction strategies chosen by managers will do. Managers likely have heightened incentive to show better after-tax performance in order to justify their compensation to new institutional investors who, as new owners, are likely to more keenly assess the pay-performance relation. ${ }^{3}$ In this scenario taxes are just another line-item expense, and institutional owners do not have to explicitly dictate which line item - taxes, R\&D, advertising, payroll, or other expenses - managers should manage better. Instead, their

\footnotetext{
${ }^{2}$ On the other hand, Porter (1992) suggests that quasi-indexers' diversified holdings reduce their incentives to monitor managers.

${ }^{3}$ For example, State Street Global Advisors notes in its March 2015 Proxy Voting and Engagement Guidelines that it "supports management proposals on executive compensation where there is a strong relation between executive pay and performance." Vanguard notes in a similar document that it considers "effective linkage between pay and performance over time."
} 
expectation is simply of higher profit margin, and managers then determine how to increase profitability. As such, as long as tax avoidance is one strategy employed by managers to improve after-tax performance, we expect a positive relation between tax avoidance and institutional ownership even in the absence of institutional owners specifically and explicitly promoting tax avoidance.

Second, tax avoidance is a politically charged topic that can attract unfavorable attention from media, government, and consumer and public interest groups toward both the firm and its large investors in a phenomenon referred to as "tax-shaming" (Barford and Holt 2013). Many quasi-indexers manage pension and other funds for large portions of the general public, and taxshaming could result in adverse private consequences for managers of these funds. Of course, these same fund managers would likely enjoy private benefits (e.g., compensation and job prospects) from tax avoidance that results in improved firm and fund performance. This implies that institutional investors are unlikely to explicitly promote tax avoidance, relying instead on the latent demand implicit in their demand for better firm financial performance or on private communication to that effect. As an example, many public pension funds conspicuously stayed silent even when prompted by media for their comments on tax inverters in their investment portfolios, implying some tacit approval from these funds (Sorkin 2014). Overall, our hypothesis is that managers "deliver" tax avoidance when institutional ownership increases, rather than that institutional owners explicitly and specifically demand tax avoidance. ${ }^{4}$

A key issue in testing the relation between tax avoidance and institutional ownership is that institutional ownership is endogenous. We overcome this hurdle by exploiting exogenous shocks to institutional ownership resulting from the annual reconstitution of the Russell 1000 and

\footnotetext{
${ }^{4}$ Some institutional investors appear to publicly indicate an interest in certain tax issues as suggested in the proxy voting guidelines of Blackrock and Vanguard (available at www.blackrock.com and www.vanguard.com).
} 
2000 indices (Chang, Hong, and Liskovich 2015; Boone and White 2015). Each June, Russell assigns firms by market capitalization into the 1000 Index (largest 1000 firms) and the 2000 Index (next-largest 2000 firms). The Russell indices are mimicked by many institutional investors (quasi-indexers), and therefore the annual reconstitution leads to changes in institutional holdings that are plausibly exogenous to the firm.

In conjunction with the exogenous shock, our empirical strategy employs a regression discontinuity design (RDD) that permits cleaner identification. Two key features of the Russell 1000 and 2000 indices facilitate the RDD. First, while firms can influence their market capitalization, they likely have less control over their relative market capitalization ranking. The Russell index assignment is determined by relative size, rather than size itself. As such, firms at the threshold between the Russell 1000 and 2000 indices (hereafter "threshold") likely have imperfect control over which index they are assigned to, implying that assignment at the threshold is effectively locally randomized. Second, since the Russell 1000 and 2000 are valueweighted benchmarks, quasi-indexers can minimize transaction costs without significantly increasing tracking error by avoiding holding firms at the bottom of each index (since the weights on the smallest firms in each index are effectively negligible). Due to this, Chang et al. (2015) show that stocks at the top of the Russell 2000 have index weights that are ten times (10 $\mathrm{x})$ the index weights of firms at the bottom of the Russell 1000. As a result, firms that cross the threshold by migrating from the bottom of the Russell 1000 to the top of the Russell 2000 have a significant and discontinuous jump in institutional ownership.

It is useful to note another important feature of this setting: There is typically a sizable positive correlation between institutional ownership and firm size that has the potential to confound inferences relating to institutional ownership. In the Russell index setting however, this 
positive correlation is broken at the threshold. Firms that become smaller and move from the bottom of the 1000 to the top of the 2000 index experience a discontinuous increase in institutional ownership.

The key to the RDD identification strategy is to show that a discontinuous jump in institutional ownership at the threshold is followed by a similar discontinuous jump in tax avoidance at the threshold. As such, the RDD compares firms in the immediate neighborhood of the threshold. This is important because any alternative explanation relying on an omitted variable $\mathrm{X}$ (for example, $\mathrm{X}=$ firm performance) has to show that $\mathrm{X}$ similarly jumps discontinuously at, rather than changing smoothly across, what is essentially an arbitrary threshold used by Russell Investments. Collectively the identification strategy adopted here mitigates concerns about endogeneity.

We use measures of tax avoidance that are common in the prior literature (Hanlon and Heitzman 2010; Chen et al. 2010; Cheng et al. 2012; Badertscher et al. 2013; McGuire et al. 2014). The primary measures are effective tax rate (ETR) measures: The GAAP ETR and the Cash ETR which are, respectively, the ratio of tax expense and the ratio of cash taxes to pre-tax income. These measures reflect non-conforming tax avoidance and are appropriate for our sample of public companies where reported book income is important to investors (Hanlon and Heitzman 2010). Results are robust to measures of the difference between book income and estimated taxable income (BTD): The Manzon and Plesko (2002) BTD and the Desai and Dharmapala (2006) abnormal BTD. For ease of presentation we adjust the signs of the tax avoidance measures so that an increase in any measure indicates an increase in tax avoidance. ${ }^{5}$

\footnotetext{
${ }^{5}$ Since a decrease in ETR measures indicates an increase in tax avoidance, we multiply the ETR measures by -1 so that higher ETR, like higher BTD, indicates higher tax avoidance.
} 
We refer to firms immediately to the right of the threshold and falling at the top of the Russell 2000 as treatment firms, and firms immediately to the left of the threshold and falling at the bottom of the Russell 1000 as control firms. Results indicate that there is no discontinuity at the threshold in 16 of 17 firm characteristics that have previously been shown to determine tax avoidance (e.g., Chen et al. 2010), and a sharp discontinuity in institutional ownership as expected. ${ }^{6}$ Non-parametric estimation of an RDD reveals a sharp and significant discontinuity in tax avoidance at the threshold, with ETR and CETR being five to seven percentage points higher for treatment firms compared to control firms. To hone the evidence further, we conduct a switching analysis by examining tax avoidance at firms that switch from one index to another, at the threshold, in a given year. Results indicate significant increases in tax avoidance for firms that move down from the bottom of the Russell 1000 to the top of the Russell 2000. Finally, in falsification tests we examine whether there are discontinuities in tax avoidance at random thresholds such as 500, 1500, 2000, and 2500, and do not find any discontinuities as expected.

We next examine the form of tax avoidance and how firms benefit from tax avoidance following Russell 2000 inclusion, in order to shed some light on the economics of the tax avoidance decision. Tax avoidance encompasses activities that form a spectrum of aggressiveness. We expect the incremental tax avoidance following Russell 2000 inclusion is more likely to come from the relatively more aggressive, rather than the relatively less aggressive, side of this spectrum, if firms have previously already exploited some tax avoidance activities (i.e., as long as prior tax avoidance is not zero on average). As such, we examine tax shelters as they represent the more aggressive segment of the spectrum of tax avoidance activities and indicate intentional tax planning (Hanlon and Heitzman 2010; Wilson 2009).

\footnotetext{
${ }^{6}$ One firm characteristic, sales growth, is significantly lower for firms at the top of the Russell 2000 compared to firms at the bottom of the Russell 1000 .
} 
Results indicate a significant discontinuity in the use of tax shelters at the Russell 2000 threshold, indicating that firms just to the right of the threshold are significantly more likely to use tax shelters than firms just to the left of the threshold.

The final set of tests examines some immediate benefits from tax avoidance. Graham, Hanlon, Shevlin, and Shroff (2014) report survey evidence that 57 percent of CEOs view increasing earnings as an important outcome of tax planning, and Dhaliwal, Gleason, and Mills (2004) suggest tax planning can be used to meet or beat earnings targets. We find a significant discontinuity in net income to sales margins, and the likelihood of meeting or beating analyst earnings forecast targets (MBE), at the Russell 2000 index threshold. This result indicates that firms just to the right of the threshold have significantly higher net income margins and likelihood of MBE than firms just to the left of the threshold.

One potential concern is the role of declining firm performance in explaining our results, since declining performance can move firms from the Russell 1000 to the Russell 2000. On one hand this concern is supported by the significantly lower sales growth, one performance measure, for firms at the top of the Russell 2000 relative to firms at the bottom of the Russell 1000. On the other hand this concern is mitigated by some considerations: (i) an improvement (rather than decline) in firm performance can move firms to the top of the Russell 2000 from lower within the Russell 2000; (ii) there is no significant discontinuity at the Russell 2000 threshold in other firm characteristics often used to capture performance, including profitability; and (iii) the results remain robust in panel regressions where we control for a host of firm characteristics, and in falsification tests around pseudo-thresholds.

This paper is related to parallel papers by Chen, Huang, Li, and Shevlin (CHLS 2015) and Bird and Karolyi (BK 2016), who also use the Russell index setting to examine institutional 
ownership and tax avoidance. In Appendix 2 we tabulate a comparison between these papers as a snapshot of key differences and similarities in sample, methodology, and results. We describe them here and also at the relevant places later in the text. In terms of sample, ours covers 19 years (1988-2006), in contrast to the 11 years (1996-2006) in CHLS and BK. This is a meaningful increase in sample size because the Russell index is reconstituted only once a year. In terms of methodology we closely follow Boone and White (2015) in non-parametrically estimating an RDD in the main tests, while CHLS and BK use parametric or semi-parametric methods. ${ }^{7}$ Another methodological issue is which data points to use in identifying the discontinuity at the threshold (bandwidth issue). In this paper, we use firms very close to the threshold in identifying the discontinuity using the theoretically optimal bandwidth derived in Calonico, Cattaneo, and Titiunik (2014), since these firms are more similar to each other. CHLS use fixed (but reasonable) bandwidths of 500 to 300 firms, but BK use all firms in the Russell 1000 and 2000 indices regardless of distance from the threshold in their main tests. Firms become less similar as their distance from the threshold grows, and as Lee and Lemieux (2010) note, using "data far away from the cutoff point to predict the value of $\mathrm{Y}$ at the cutoff point is not intuitively appealing."

Finally, in terms of results, all three papers find a significantly positive relation between institutional ownership and tax avoidance for all tax avoidance measures, with similar magnitudes where comparable. We, and BK, find significant use of tax shelters, while CHLS do not. To balance out the evidence on costly tax avoidance, we further document benefits in the

\footnotetext{
${ }^{7}$ Non-parametric (parametric) estimates are free from (dependent on) assumptions about the underlying functional form. Lee and Lemieux $(2010,316)$ note that "(T)he consequences of using an incorrect functional form are more serious in the case of RD designs however, since mis-specification of the functional form typically generates a bias in the treatment effect, $\tau$. This explains why, starting with Hahn, Todd, and van der Klaauw (2001), the estimation of $\mathrm{RD}$ designs have generally been viewed as a nonparametric estimation problem.” Further, Angrist and Pischke (2009) note that, in the presence of an unknown functional form, it is easy for a continuous but nonlinear relation at the threshold to be mistaken for a discontinuity at the threshold. These observations motivate our preference for nonparametric estimation of the RDD.
} 
form of higher net income margins and likelihood of meeting or beating analyst earnings forecasts (unexamined in CHLS and BK). CHLS find that results are largely unaffected by corporate governance and firm information environment, while BK find some effect of corporate governance. We find some evidence for an executive equity compensation effect through delta and vega (Core and Guay 1999; Guay 1999), while BK also find an effect through the level of equity compensation. CHLS find an effect in federal and state taxes but not foreign taxes, while BK find an effect in foreign tax havens.

This paper is also related to Khurana and Moser (2013) who examine the relation between institutional investors and tax avoidance, but is distinct in two important ways: (i) Our empirical identification strategy exploits an exogenous shock to institutional ownership and a regression discontinuity design to overcome concerns about endogeneity; and, (ii) Using more powerful tests we find a positive relation between institutional ownership and tax avoidance, in contrast to the negative relation documented in Khurana and Moser (2013).

The results contribute to the literature on corporate income tax avoidance. Dyreng et al. (2010) note that evidence on the determinants of tax avoidance remains limited despite longstanding and widespread interest in the area, and Hanlon and Heitzman (2010) encourage researchers to explore agency frictions as an explanation. Our results suggest that an increase in ownership concentration increases tax avoidance. We further provide evidence on some immediate costs and benefits associated with tax avoidance, thereby shedding light on the economic tradeoffs involved.

The rest of this paper proceeds as follows. Section II provides some background on the prior literature and the empirical setting. Section III describes the regression discontinuity design and the data. Section IV presents the main empirical results, and Section V describes the audit 
fee tests. Section VI describes additional tests, and Section VII concludes. Appendix 1 presents detailed data definitions, and Appendix 2 tabulates a comparison between this paper, CHLS (2015) and BK (2016).

\section{BACKGROUND}

In this section we describe the prior literature on corporate tax avoidance and the Russell index reconstitution setting.

\section{Tax Avoidance and Agency Frictions}

Tax avoidance, or the reduction of explicit taxes, is the outcome of a spectrum of activities ranging from investments in tax-exempt assets such as municipal bonds to aggressive non-compliance schemes. As in the prior literature (Hanlon and Heitzman 2010), we adopt an "outcome-based" rather than an "input-based" definition and do not distinguish between the types of activities that result in the reduction of explicit taxes. Corporate tax avoidance is of significant interest to a variety of groups but academic understanding of its determinants, unlike that for individual tax avoidance, is still evolving and has led tax scholars to call for further research (Shackelford and Shevlin 2001; Hanlon and Heitzman 2010).

A more recent theory of corporate tax avoidance is developed in Slemrod (2004), Crocker and Slemrod (2005), and Chen and Chu (2005) who propose a role for manager-shareholder agency conflicts in determining tax avoidance. Are managers misaligned with shareholders in setting the level of tax avoidance? Some recent evidence on this question is provided in Chen et al. (2010), Cheng et al. (2012), Badertscher et al. (2013), and McGuire et al. (2014). We build directly on the agency perspective and examine whether higher institutional ownership is associated with higher tax avoidance. 
Bushee $(1998,2001)$ classifies institutional investors in terms of their horizon and diversification. Transient institutional investors have short horizons, trade frequently, and are diversified. Quasi-indexers have long horizons and are diversified. Dedicated investors have long horizons and concentrated holdings. Of these three types of institutional investors, transient investors are less likely to expend effort to monitor and advocate on shareholder behalf because structural changes are unlikely to occur and bear fruit within their short trading horizon (Boone and White 2015). Quasi-indexers on the other hand have a fiduciary duty to preserve shareholder value, and the leverage to influence managerial actions (Monks and Minow 1995). In addition, their inability to exit investments at will (or "vote with their feet") could increase their incentives to monitor and advocate at any individual firm. Finally, dedicated investors have the incentive and ability to monitor and advocate, but are not the subject of this study since their holdings do not respond mechanically to index reconstitution.

A key contribution of this study is to overcome the endogeneity of ownership concentration more effectively through an exogenous shock to institutional ownership as described next.

\section{The Russell Index Reconstitution Setting}

The Russell 1000 (2000) index consists of the largest 1000 (next-largest 2000) publicly listed firms by market capitalization. Russell Investments assigns firms to these value-weighted indices based on their market value on the last trading day of May each year, and calculates their index weights on the last Friday of June. Depending on their relative market capitalization firms can move from one index to another. At the threshold between the 1000 and 2000 indices in particular, small changes in relative market capitalization can result in reassignment from one index to another. 
Considerable institutional capital is benchmarked to the Russell 1000 and 2000 indices. Chang et al. (2015) report that $\$ 169$ billion ( $\$ 264$ billion) is benchmarked to the 1000 (2000) index in 2008. Indexing strategies attempt to minimize benchmark tracking error, and since the Russell indices are value-weighted, firms at the top of each index (the largest firms in that index) are much more important sources of tracking error than firms at the bottom of each index (the smallest firms in that index). In particular, since the weights on firms at the bottom of these indices are relatively trivial, quasi-indexers can avoid the transaction costs associated with holding the smallest firms in any given index without significantly increasing index tracking error. This leads to a significant asymmetry in institutional ownership at the threshold of the 1000 and 2000 indices: While firms on either side of the threshold are similar in size, firms at the top of the Russell 2000 have ten times the index weights of firms at the bottom the Russell 1000 (Chang et al. 2015). Firms at the bottom of the 1000 index therefore have low institutional ownership, while firms at the top of the 2000 index have high institutional ownership.

The Russell index reconstitution setting has been used in Boone and White (2015), Chang et al. (2015), and Appel, Gormley, and Keim (2016), among others, to examine the relation between institutional ownership and management earnings forecasts, price pressure from index changes, and corporate governance. We extend this literature by examining the effect of institutional ownership on corporate tax avoidance.

\section{EMPIRICAL IDENTIFICATION STRATEGY, AND DATA}

We exploit firms at the threshold between the 1000 and 2000 indices for sharp identification. Small relative movements in market capitalization can cause threshold firms in the 1000 index to be reassigned to the 2000 index or vice versa, and thereby to experience a 
significant change in institutional ownership. In the language of the regression discontinuity design (RDD), market capitalization is expected to be locally smooth across the threshold, but institutional ownership is expected to jump discontinuously at the threshold. We therefore use a RDD to test for discontinuities in tax avoidance at the threshold. As long as firms cannot precisely manipulate their relative market capitalization ranking, index assignment at the threshold is effectively locally randomized (Lee and Lemieux 2010).

The RDD is estimated non-parametrically (Hahn, Todd, and Van der Klaauw 2001; Lee and Lemieux 2010; Tan 2013; Gao, Khan, and Tan 2016) to allow flexible function forms. As Lee and Lemieux (2010) note, the inclusion of baseline covariates (independent variables) is irrelevant in the RDD given the locally randomized assignment to the treatment sample (and we verify in Section 4.1 below that firms around the threshold do not have significant differences in firm characteristics, consistent with locally randomized assignment). Essentially the RDD can be seen as testing whether tax avoidance at firms just to the left of the threshold differs from tax avoidance at firms just to the right of the threshold. If assignment of firms immediately to the left or the right of the threshold is effectively locally randomized, then the two sets of firms are expected to be identical in all dimensions except for the treatment effect. We use the theoretically derived optimal bandwidth from Calonico et al. (2014) to determine the number of firms on either side of the threshold used to identify the discontinuity. (In robustness tests we also estimate a parametric panel regression of tax avoidance on its known determinants from the prior literature). Our methodology differs from CHLS (2015) and BK (2016) who use parametric or semi-parametric methods to identify the discontinuity in their main tests. In model estimation, BK also use all firms in the Russell 1000 and 2000 indices regardless of distance from the threshold in their main tests. 
The data on the Russell index constituents and weights are from Russell Investments and cover the period 1979-2013. As in Chang et al. (2015) and Boone and White (2015), we do not use post-2006 data because Russell Investments initiated a banding policy in 2007 to reduce index turnover by keeping threshold index members in their original index if their market capitalization did not change significantly. As such, we begin with 1979-2006 data from Russell Investments. The institutional ownership data are from Thompson, and accounting data are from Compustat. Data from the Statement of Cash Flows is available from 1988 on Compustat, and is needed to calculate the cash ETR tax avoidance measure. As such, our final sample covers the 19 years from 1988 to 2006 . It is important to note that time-series length is particularly helpful since the Russell index is reconstituted once a year. CHLS (2015) and BK (2016) in contrast have 11 years of data (1996-2006) in their sample.

Our primary tax avoidance measures are the GAAP effective tax rate, ETR, and the cash effective tax rate, cash ETR. ETR is the tax expense as a percent of pretax income, and captures tax avoidance resulting from permanent book-tax differences rather than from tax deferral. Investments in tax-exempt assets such as municipal bonds, and foreign earnings permanently reinvested in a lower tax jurisdiction, are examples of tax avoidance strategies that would be reflected in the ETR. Cash ETR is the cash taxes paid as a percent of pretax income, and captures tax avoidance resulting from deferral strategies. In addition, unlike the ETR, the cash ETR is not affected by items such as changes in the tax contingency reserves that are not tax planning strategies (Hanlon and Heitzman 2010). Both ETR and cash ETR are widely used tax avoidance measures. We multiply both ETR and CETR by -1 so that an increase in ETR or CETR reflects an increase in tax avoidance. 


\section{RESULTS ON INSTITUTIONAL OWNERSHIP AND TAX AVOIDANCE Timing of Dependent Variables}

Figure 1 illustrates the timing of the dependent variables used in our tests. Firms are added to the Russell 2000 index at the end of June each year, and at this point experience an increase in institutional ownership. The issue is how much time to allow managers to respond to this change by increasing tax avoidance activities. Consider a firm with December fiscal yearend which is added to the Russell 2000 on June 30, 2001. If we examine its ETR from financial statements dated December 31, 2001 then we have effectively allowed managers only six months to respond, which may be insufficient time. We therefore calculate ETR and CETR from financial statements dated December 31, 2002 for this firm, effectively allowing managers 18 months to respond for December fiscal-year-end firms. More generally Figure 1 shows that for about 86 percent of firm-years corresponding to firms with fiscal year-end from June through December, the managerial response time we allow increases from 12 months to 18 months, respectively. For less than 14 percent of firm-years corresponding to firms with fiscal year-end from January through May, the managerial response time we allow increases from 7 months to 11 months, respectively. Results are robust to using only firms with June through December fiscal year-end.

\section{< INSERT FIGURE 1 ABOUT HERE >}

\section{Descriptives}

Panel A of Figure 2 shows index weights of firms in the Russell 1000 and 2000 indices. $^{8}$ The "cutoff" for index assignment is the threshold between the indices, and firms to the left (right) of the cutoff are in the 1000 (2000) index. Index weights decline considerably from the

\footnotetext{
${ }^{8}$ The Russell 1000/2000 indexes include common equities, and exclude preferred stocks, closed-end mutual funds, limited partnerships, royalty trusts, and REITs.
} 
top to the bottom of the 1000 , but exhibit a sharp and discontinuous tenfold jump at the cutoff, implying that index weights for firms at the top of the 2000 index are discontinuously higher than those for firms at the bottom of the 1000 index. Panels B through E show total institutional ownership, dedicated investor ownership, quasi-indexer ownership, and transient investor ownership, respectively, in firms around the cutoff. The graphs show a large discontinuity in total, quasi-indexer, and transient institutional investor ownership at the cutoff such that ownership is higher at the top of the 2000 index than at the bottom of the 1000 index. In contrast, dedicated investor ownership in Panel C appears lower for firms at the top of the 2000 index than for firms at the bottom of the 1000 index.

\section{< INSERT FIGURE 2 ABOUT HERE >}

Panels A and B of Figure 3 show the tax avoidance measures for firms in the 1000 and 2000 indices. Both ETR and CETR exhibit a discontinuity at the cutoff that mirrors the discontinuity in quasi-indexer ownership seen in Figure 2. The statistical significance of these patterns is examined shortly.

\section{< INSERT FIGURE 3 ABOUT HERE >}

Table 1 reports the distribution of variables used in the study for the 200 firms at the bottom of the Russell 1000 index (left of the threshold) and the 200 firms at the top of the Russell 2000 index (right of the threshold). The mean ETR and CETR of -0.33 and -0.27 , respectively, for firms on the left indicate an effective tax rate of 33 percent and a cash effective tax rate of 27 percent (recall that we have multiplied ETR and CETR by -1). For firms on the

right, the mean ETR and CETR are 31 percent and 26 percent, respectively. Mean institutional ownership is 48 percent (55 percent) for firms on the left (right), while mean quasi-indexer ownership is 29 percent (35 percent) for firms on the left (right). Table 2 reports correlations 
between the variables. ETR and CETR have a Pearson (Spearman) correlation of 0.42 (0.41), indicating ETR and CETR capture some common, but also some distinct, aspects of tax avoidance.

\section{< INSERT TABLE 1 ABOUT HERE > \\ < INSERT TABLE 2 ABOUT HERE >}

Table 3 examines the statistical significance of the discontinuity in institutional ownership at the cutoff. Panel A reports mean differences in institutional ownership, while Panel B reports RDD estimates of the discontinuity in institutional ownership at the threshold. There are four rows of estimates in Panel A, one each for total institutional ownership, dedicated investor ownership, quasi-indexer ownership and transient investor ownership. The panel shows average institutional ownership for bandwidths of 200, 100, and 50 firms on either side of the cutoff as indicated in the column headers. The bandwidth choice involves a tradeoff between efficiency and bias, and we therefore examine three different bandwidths. The columns labeled "Difference" show statistical significance from tests of differences in average institutional ownership between firms at the left versus the right of the cutoff. Panel A of Table 1 reveals two patterns: Firms at the top of the Russell 2000 have significantly higher total, quasi-indexer, and transient institutional ownership than firms at the bottom of the Russell 1000, on average; and, the magnitude of the difference increases as we zoom closer to the cutoff by decreasing the bandwidth examined. The difference in averages from smaller bandwidths approaches the estimate of discontinuity at the cutoff.

\section{$<$ INSERT TABLE 3 ABOUT HERE >}

Panel B of Table 3 shows the magnitudes and statistical significance of RDD estimates of the discontinuity in institutional ownership at the index threshold. The non-parametric estimates 
use the optimal bandwidth and a triangle kernel from Calonico et al. (2014). The kernel controls the weights placed on observations, with a triangle kernel placing more weight on observations closer to the threshold (Lee and Lemieux 2010). Panel B formally shows significant discontinuities in total, quasi-indexer, and transient institutional ownership at the threshold, with quasi-indexer ownership being 19.9 percentage points higher for firms at the top of the 2000 index relative to firms at the bottom of the 1000 index.

\section{Main Results}

Panel A of Table 4 examines bandwidths of 200, 100, and 50 firms on either side of the threshold, and shows means of various firm characteristics. The firm characteristics are those shown in the prior literature to be determinants of tax avoidance (e.g., Chen et al. 2010). The panel shows that firms at the top of the 2000 index are significantly smaller than firms at the bottom of the 1000 index, by construction, and generally shows insignificant differences except for some variables and some bandwidths. Given the large number of firm characteristics and various bandwidths tested, some randomly significant differences are not unexpected.

\section{< INSERT TABLE 4 ABOUT HERE >}

More important for our purposes is to test for any discontinuity in firm characteristics at the threshold. We do this in Panel B of Table 4, which shows no significant discontinuity in any firm characteristic except sales growth. In particular, while Panel A shows a significant difference in firm size on either side of the threshold, Panel B shows that firm size changes smoothly, not discontinuously, at the threshold. In other words, firm size does not jump discontinuously at the threshold. This smoothness is explained by the fact that index assignment depends on relative size, so there is no reason to expect a discontinuity in size at the threshold. 
Collectively the results in Panels A and B of Table 4 are consistent with the notion that index assignment at the threshold is effectively locally randomized, which supports the validity of RDD tests on tax avoidance (Lee and Lemieux 2010). However, to the extent the significant discontinuity in sales growth weakens the locally randomized assignment requirement for RDD, the effectiveness of the RDD is subject to qualification.

\section{Non-parametric Tests}

Panel A of Table 5 shows mean differences in ETR and CETR for bandwidths of 200, 100, and 50 firms around the threshold. The table shows significant mean differences in both tax avoidance measures as we zoom closer to the threshold by examining smaller bandwidths. The magnitudes of the differences are also larger as the bandwidth narrows. Panel B of Table 5 formally tests for a discontinuity in tax avoidance around the threshold using a non-parametric RDD method that does not rely on assuming a specific functional form for how tax avoidance varies with the distance from the threshold. In other words, the non-parametric method fits the function to the data. As panel B shows, non-parametric RDD estimates of tax avoidance are statistically significant for both measures at p-values $<0.01$, indicating that tax avoidance jumps discontinuously at the Russell index threshold. The magnitudes of the discontinuity estimates range from 5.1 percent for total ETR to 7 percent for cash ETR. These results are consistent with those in CHLS (2015) and BK (2016).

\section{< INSERT TABLE 5 ABOUT HERE >}

\section{Switching Analysis}

In order to enhance identification we examine tax avoidance only at firms that switch from the Russell 1000 to the 2000 index (excluding firms that never switch) within a narrow (optimal) bandwidth close to the threshold. The switching sample includes one pre-switch and 
one post-switch observation for each switching firm, effectively comparing the average dependent variable after the switch relative to the average dependent variable prior to the switch. Panel C of Table 5 shows RDD estimates of the discontinuity in tax avoidance as firms switch into the Russell 2000 index. Both tax avoidance measures show a significant increase (p-value < 0.01) in tax avoidance as firms move down to the Russell 2000 index. The switching sample analysis is not available in CHLS (2015), or in BK (2016) for firms switching within a narrow bandwidth of the threshold (BK include all switchers regardless of distance from the threshold in their tests).

\section{Falsification Tests}

In our setting, the treatment effect (an exogenous increase in institutional ownership) is administered when a firm crosses from the Russell 1000 to the 2000 index, and this threshold between the two indices is where we look for a discontinuous jump in tax avoidance. The implication is that the tax avoidance is a consequence of the treatment. As a falsification test we also examine whether there is a discontinuity in tax avoidance around a series of hypothetical Russell index cutoffs. In particular, we examine whether there is a discontinuity in tax avoidance at firms immediately to the right, versus immediately to the left, of the Russell 500 cutoff, and repeat this exercise for the Russell 1500, 2000, and 2500 cutoffs. Results shown in Panel D of Table 5 indicate no significant discontinuity in tax avoidance at any of these cutoffs, as expected. A falsification test at pseudo-thresholds is also available in CHLS (2015) and BK (2016).

This test is also helpful in mitigating a potential concern that a decline in firm performance moves firms from the bottom of the Russell 1000 to the top of the Russell 2000, and that declining firm performance explains the increase in tax avoidance. The same declining firm performance can similarly lead firms from the left to the right of the 500, 1500, 2000, and 2500 
thresholds, but we do not observe a discontinuity in tax avoidance at these thresholds. This appears more consistent with tax avoidance being associated with changes in institutional ownership at the 1000 threshold, rather than with declining firm performance.

Collectively the results in Table 5 provide strong evidence of the impact of quasiindexers on corporate tax avoidance.

\section{FORM AND BENEFITS OF TAX AVOIDANCE}

In this section we examine the form of tax avoidance and the economics of the decision. Section 5.1 explores the use of tax shelters following Russell 2000 inclusion. Section 5.2 explores immediate benefits of tax avoidance in the form of net income margins and the likelihood of meeting or beating earnings targets.

\section{Tax Shelters}

Tax avoidance results from activities that cover a spectrum of aggressiveness, ranging from the use of available tax exemptions to more complicated schemes that test the boundaries of compliance. We examine the use of tax shelters following Russell 2000 inclusion. Tax shelters cover the more aggressive segment of the avoidance spectrum, and are likely to be used if firms have already previously exploited the "easier" or less aggressive avoidance strategies. We use a model-implied measure of the use of tax shelters as developed in Wilson (2009), which is based on firm characteristics known to be associated with tax shelter use. These variables include the book-tax difference, discretionary accruals, leverage, size, profitability, foreign income, and R\&D (Wilson 2009). Table 6 shows results from non-parametric estimation of the discontinuity in tax shelter use. The analysis compares tax shelter use by firms just to the right of the Russell 2000 index threshold versus firms just to the left of the threshold. The coefficient of the Russell 
2000 indicator is significant ( $\mathrm{p}$-value $<0.01$ ), indicating that tax avoidance by firms at the top of the Russell 2000 involves the use of tax shelters. BK (2016) also find a significant use of tax shelters consistent with our results, though CHLS (2015) find no significant use of tax shelters.

\section{$<$ INSERT TABLE 6 ABOUT HERE >}

\section{Net Income Margins, and Meeting or Beating Earnings Expectations}

In order to obtain a richer picture of the economics of the tax avoidance decision we examine immediate benefits associated with tax avoidance. Tax avoidance increases after-tax income, and CEOs are reported in Graham et al. (2014) to believe that it can be used to increase earnings-per-share (EPS). In addition, Dhaliwal et al. (2004) suggest tax avoidance can be used to meet or beat analyst earnings expectations. We therefore examine net income margins and the likelihood of meeting or beating earnings expectations after Russell 2000 inclusion.

Table 7 reports results on net income margin, which is the ratio of after-tax income to sales. The analysis compares net income margins at firms just to the right, versus firms just to the left, of the Russell 2000 index threshold. The Russell 2000 coefficient in Table 7 shows that net income margins are discontinuously and significantly higher (p-value $<0.01)$ at firms at the top of the Russell 2000 index.

\section{$<$ INSERT TABLE 7 ABOUT HERE >}

Table 8 examines the likelihood of meeting or beating analyst expectations of annual earnings. The analysis compares actual earnings to the median of the last forecast of annual earnings. A firm is identified as meeting or beating the forecast if it meets or beats the consensus forecast by two cents or less. The Russell 2000 coefficient in Table 8 shows that the likelihood of meeting or beating earnings expectations is discontinuously and significantly higher (p-value < 
0.05) at firms at the top of the Russell 2000 index, compared to firms at the bottom of the Russell 1000 index.

\section{< INSERT TABLE 8 ABOUT HERE >}

Collectively the results in Tables 7 and 8 indicate that firms at the top of the Russell 2000 index have discontinuously higher outcomes in performance variables that are closely tracked by equity investors. This analysis is not available in CHLS (2015) or BK (2016).

\section{ROBUSTNESS TESTS}

\section{Multi-year Tax Avoidance Measures}

We examine three-year ETR and CETR, labeled ETR3 and CETR3, in order to shed light on long-run tax avoidance at Russell 2000 firms. In untabulated non-parametric RDD tests, the Russell 2000 coefficient is 0.047 (p-value < 0.01) when ETR3 is the dependent variable, and 0.065 (p-value $<0.01$ ) when CETR3 is the dependent variable. This indicates ETR3 and CETR3 are discontinuously higher at firms just to the right of the Russell 2000 index threshold, compared to firms just to the left of the threshold.

\section{Panel Regressions}

To obtain parametric estimates of the tax avoidance effect we estimate panel regressions of the two tax avoidance measures (ETR and CETR) on an indicator for firms in the Russell 2000 index (RU2000), indicators for firm distance, squared distance, and cubed distance on both the left and the right of the threshold (Lee and Lemieux 2010), and known determinants of tax avoidance. The distance from the threshold is such that negative (positive) distance signals inclusion in the Russell 1000 (2000) index, and controlling for the distance in the regression allows interpretation of the Russell 2000 indicator as the discontinuity at the threshold. The 
regressions control for known determinants of tax avoidance (e.g., Chen et al. 2010) including firm size, book-to-market, profitability, leverage, fixed assets (PP\&E), intangibles, the level of and change in tax-loss carryforwards, pretax foreign income, and equity income. The regressions also include industry and year fixed effects, and standard errors clustered by firm (Petersen 2009). These regressions are similar to the parametric models in CHLS (2015) and BK (2016).

Untabulated results show that the RU2000 indicator is 0.020 (p-value $<0.01$ ) when ETR is the dependent variable, and 0.024 (p-value < 0.01) when CETR is the dependent variable. The magnitudes of the discontinuity estimates are less than one-half of the non-parametric estimates in Panel B of Table 5. One reason for this is that the panel regressions fit the data to the full sample, which includes firms far from the threshold that are different from firms at the threshold. The discontinuity estimate in Table 5 in contrast is obtained by examining firms close to the threshold.

\section{Panel Regressions with Additional Controls}

We re-estimate the panel regressions with a host of other control variables. These include excess tax benefits of stock compensation since exercises of stock-based compensation affect the cash ETR, R\&D expenses to capture R\&D tax credits, advertising expenses as another proxy for intellectual property, SG\&A and capital expenditures to capture business deductions, sales growth as an additional performance measure, and the magnitude of multinationality as indicated by the ratio of foreign to total pre-tax income. Untabulated results are robust, as the coefficient of the RU2000 indicator is 0.018 (p-value < 0.01) when ETR is the dependent variable, and 0.022 (p-value $<0.01)$ when CETR is the dependent variable.

Extending the specification above, we re-estimate the regressions controlling for two measures of executive compensation incentives, delta and vega (Core and Guay 1999; Guay 
1999). Delta (vega) is the sensitivity of CEO stock and option holdings value to the stock return (stock return volatility), and managerial incentives have been shown to influence tax avoidance in Robinson, Sikes, and Weaver (2010), Rego and Wilson (2012), Gaertner (2013), and Powers, Robinson, and Stomberg (2015). Untabulated results show that the Russell 2000 indicator is no longer significant. One interpretation of this result is that changes in managerial incentives are the mechanism through which changes in tax avoidance are incentivized. Consistent with this, we find significant discontinuities in delta and vega at the Russell index threshold. This appears to be an opportunity for future research.

BK (2016) also examine the effect of executive equity compensation (CHLS do not) using the level of equity compensation and stock options as proxies. We follow Core and Guay (1999) and Guay (1999) in using delta and vega as better measures of executive equity incentives. BK (2016) find some evidence that tax avoidance occurs more in firms with previously low executive equity compensation, suggesting somewhat similar inferences as our result.

\section{Other Tax Avoidance Measures}

Two other tax avoidance measures used in the literature are based on differences between book income and estimated taxable income (Hanlon and Heitzman 2010; Chen et al. 2010; Cheng et al. 2012; Badertscher et al. 2013; McGuire et al. 2014). These are the Manzon and Plesko (2002) BTD and the Desai and Dharmapala (2006) abnormal BTD. The abnormal BTD controls for earnings management in an effort to capture intentional, rather than coincidental, tax avoidance. A portion of both BTD measures impacts accounting earnings, and they both reflect deferral strategies and nonconforming tax avoidance (Hanlon and Heitzman 2010). We therefore examine robustness with respect to these measures of tax avoidance. 
Untabulated non-parametric RDD estimates of the discontinuity in the two BTD measures at the threshold of the Russell 1000 and 2000 indices show that results remain robust. When estimated in the full sample, the discontinuity estimate in BTD is 0.025 (p-value $<0.01$ ), and the discontinuity estimate in abnormal BTD is 0.022 (p-value $<0.01$ ). When estimated in the sample of firms that switch into the Russell 2000, the discontinuity estimate in BTD is 0.090 (pvalue $<0.01$ ), and the discontinuity estimate in abnormal BTD is 0.070 (p-value $<0.01$ ). These results are consistent with CHLS (2015) and BK (2016) who also use book-tax difference proxies for tax avoidance.

\section{CONCLUSION}

In this paper, we find a significantly positive relation between institutional ownership and corporate income tax avoidance. Using an exogenous shock to quasi-indexer institutional ownership upon inclusion of firms to the Russell 2000 index, and a regression discontinuity design to facilitate sharper identification of treatment effects, we document significant discontinuities in effective tax rate measures and book-tax difference measures when firms are added to the Russell 2000. The results suggest ownership concentration has explanatory power for variation in tax avoidance (Slemrod 2004; Chen and Chu 2005; Crocker and Slemrod 2005; Hanlon and Heitzman 2010).

We further examine the nature of tax avoidance activities and some immediate costs and benefits of tax avoidance for firms at the top of the Russell 2000 compared to firms at the bottom of the Russell 1000. Results indicate an increase in the use of tax shelters, which is a costly activity in the sense that tax shelters occupy the more complex segment of the spectrum of tax avoidance activities. Results also indicate an increase in net income margins and higher 
likelihood of meeting or beating analyst earnings expectations at firms at the top of the Russell 2000, suggesting some immediate benefits of tax avoidance.

Collectively the results respond to the call in Hanlon and Heitzman (2010) for evidence on determinants of corporate tax avoidance, and shed light on ownership concentration as an explanation for variation in tax avoidance. The results also add to an understanding of the immediate costs and benefits of tax avoidance.

Combined with the results in Chen et al. (2015) and Bird and Karolyi (2016) who use different samples and methodologies, we view the positive relation between ownership concentration and tax avoidance as quite robust, and novel given the opposite conclusion from cross-sectional regressions in Khurana and Moser (2013). If tax planning is a costly and risky investment, it is helpful to have a sense of the costs and benefits. In this regard, our results and those of BK (2016) suggest that relatively more costly tax avoidance strategies (in the form of shelters) are used, and our results suggest capital market benefits through higher net income margins and meeting earnings expectations. Regarding the mechanism, our results and those of BK (2016) suggest executive equity incentives play a role in explaining tax avoidance. BK (2016) also suggest governance in the form of board changes as a mechanism, though our view is that board changes are perhaps a substantially more costly and visible mechanism than might be necessary. Institutional owners likely wield influence in more subtle ways, through their say-onpay, engagement in the form of "hundreds of direct discussions every year" with managers, and an "approach of quiet diplomacy" (Booraem 2013). Empirically identifying these subtle and perhaps varied mechanisms could potentially require new and perhaps hand-collected data. This represents one opportunity for future research. 
Finally, one aspect we do not have insight on from any of the three papers is where the tax planning advice is acquired from. For example, do institutional owners themselves suggest specific tax avoidance strategies, and if so where do they acquire this knowledge from? Do firms tap into in-house tax planning expertise? Or do firms acquire advice from newly retained consultants? This represents another opportunity for future research, and answers to these questions can help round out our understanding of the role of ownership structure in corporate tax avoidance. 


\section{REFERENCES}

Angrist, J., and J. Pischke. 2009. Mostly Harmless Econometrics: An Empiricist's Companion. Princeton, NJ: Princeton University Press.

Appel, I., T. Gormley, and D. Keim. 2016. Passive Investors, Not Passive Owners. Forthcoming, Journal of Financial Economics.

Badertscher, B., S. Katz, and S. Rego. 2013. The separation of ownership and control and corporate tax savings. Journal of Accounting \& Economics 56: 228-250.

Barford, V., and G. Holt. 2013. Google, Amazon, Starbucks: The rise of "tax shaming." BBC News Web site (May 21). Available at: http://www.bbc.com/news/magazine-20560359

Bird, A., and S. Karolyi. 2016. Governance and Taxes: Evidence from Regression Discontinuity. Forthcoming, The Accounting Review.

Boone, A., and J. White. 2015. The effect of institutional ownership on firm transparency and information production. Journal of Financial Economics, 117: 508-533 .

Booraem, G. 2013. Passive investors, not passive owners. Available at: https://personal.vanguard.com/us/insights/article/proxy-commentary-042013

Bushee, B. 1998. The influence of institutional investors on myopic R\&D investment behavior. The Accounting Review 73 (3): 305-333.

Bushee, B. 2001. Do institutional investors prefer near-term earnings over long-run value? Contemporary Accounting Research 18 (2): 207-246.

Calonico, S., M. Cattaneo, and R. Titiunik. 2014. Robust nonparametric confidence intervals for regression-discontinuity designs. Econometrica 82: 2295-2326.

Calonico, S., M. Cattaneo, and R. Titiunik. 2015. Optimal data-driven regression discontinuity plots. Journal of the American Statistical Association (forthcoming).

Chang, Y.-C., H. Hong, and I. Liskovich. 2015. Regression discontinuity and the price effects of stock market indexing. Review of Financial Studies 28: 212-246.

Chen, K.-P., and C. Chu. 2005. Internal control vs. external manipulation: A model of corporate income tax evasion. RAND Journal of Economics 36: 151-164.

Chen, S., X. Chen, Q. Cheng, and T. Shevlin. 2010. Are family firms more tax aggressive than non-family firms? Journal of Financial Economics 95: 41-61. 
Chen, S., Y. Huang, N. Li, and T. Shevlin. 2015. Quasi-indexer Ownership and Corporate Tax Planning. Working paper, University of Texas-Austin, University of Texas-Dallas, and University of California-Irvine.

Cheng, A., H. Huang, Y. Li, and J. Stanfield. 2012. The effect of hedge fund activism on corporate tax avoidance. The Accounting Review 87: 1493-1526.

Core, J., and W. Guay. 1999. The use of equity grants to manage optimal equity incentive levels. Journal of Accounting and Economics 28: 151-184.

Crocker, K., and J. Slemrod. 2005. Corporate tax evasion with agency costs. Journal of Public Economics 89: 1593-1610.

Desai, M., and D. Dharmapala. 2006. Corporate tax avoidance and high-powered incentives. Journal of Financial Economics 79, 145-179.

Dhaliwal, D., C. Gleason, and L. Mills. 2004. Last chance earnings management: Using the tax expense to meet analyst forecasts. Contemporary Accounting Research 21: 431-459.

Dyreng, S., M. Hanlon, and E. Maydew. 2008. Long-run corporate tax avoidance. The Accounting Review 83: 61-82.

Dyreng, S., M. Hanlon, and E. Maydew. 2010. The effects of executives on corporate tax avoidance. The Accounting Review 85: 1163-1189.

Gaertner, F. 2013. CEO After-tax Compensation Incentives and Corporate Tax Avoidance. Working paper, University of Wisconsin.

Gao, Y., M. Khan, and L. Tan. 2016. Further Evidence on Consequences of Debt Covenant Violations. Working paper, Harvard University, University of Minnesota, and George Washington University.

Graham, J., M. Hanlon, T. Shevlin, and N. Shroff. 2014. Incentives for tax planning and avoidance: Evidence from the field. The Accounting Review 89: 991-1023.

Guay, W. 1999. The sensitivity of CEO wealth to equity risk: An analysis of the magnitudes and determinants. Journal of Financial Economics 53: 43-71.

Hahn, J., P. Todd, and W. Van der Klaauw. 2001. Identification and estimation of treatment effects with a regression discontinuity design. Econometrica 69: 201-209.

Hanlon, M., and S. Heitzman. 2010. A review of tax research. Journal of Accounting and Economics 50: 127-178.

Hribar, P., and D. Collins. 2002. Errors in estimating accruals: Implications for empirical research. Journal of Accounting Research 40: 105-134. 
Khurana, I., and W. Moser. 2013. Institutional shareholders' investment horizons and tax avoidance. Journal of the American Taxation Association 35: 111-134.

Lee, D., and T. Lemieux. 2010. Regression discontinuity designs in economics. Journal of Economic Literature 48: 281-355.

Manzon, G., and G. Plesko. 2002. The relation between financial and tax reporting measures of income. Tax Law Review 55: 175-214.

McGuire, S., D. Wang, and R. Wilson. 2014. Dual class ownership and tax avoidance. The Accounting Review 89 (4): 1487-1516.

Monks, R., and N. Minnow. 1995. Corporate Governance. Cambridge, MA: Blackwell.

Petersen, M. 2009. Estimating standard errors in finance panel data sets: Comparing approaches. Review of Financial Studies 22, 435-480.

Porter, M. 1992. Capital Choices: Changing the Way America Invests in Industry. Boston: Council on Competitiveness/Harvard Business School.

Powers, K., J. Robinson, and B. Stomberg. 2015. How Do CEO Incentives Affect Corporate Tax Planning and Financial Reporting of Income Taxes? Working paper, University of Texas-Austin, Texas A\&M, and University of Georgia.

Rego, S., and R. Wilson. 2012. Equity risk incentives and corporate tax aggressiveness. Journal of Accounting Research 50: 775-810.

Robinson, J., S. Sikes, and C. Weaver. 2010. Performance measurement of corporate tax departments. The Accounting Review 85: 1035-1064.

Shackelford, D., and T. Shevlin. 2001. Empirical tax research in accounting. Journal of Accounting and Economics 31: 321-387.

Slemrod, J. 2004. The economics of corporate tax selfishness. National Tax Journal 57: 877899.

Sorkin, A. R. 2014. Public pension funds stay mum on corporate expats. New York Times Dealbook Column (September 1). Available at: http://dealbook.nytimes.com/2014/09/01/public-pension-funds-stay-mum-on-corporateexpats/?_r=1

Tan, L. 2013. Creditor control rights, state of nature verification, and financial reporting conservatism. Journal of Accounting and Economics 55: 1-22.

Weisbach, D. 2002. Ten truths about tax shelters. Tax Law Review 55: 215. 
Wilson, R. 2009. An examination of corporate tax shelter participants. The Accounting Review 84: 969-999. 


\title{
Appendix 1: Variable Definitions
}

\author{
ADVERT \\ Advertising expense (XAD) / lagged total assets (AT). ADVERT is set to 0 when \\ missing. \\ $C A P X$ \\ Reported capital expenditures (CAPX) / lagged total assets (AT) \\ CETR \\ Cash effective tax rate. Cash tax paid (TXPD) / (pre-tax book income (PI) - special \\ items (SPI)). CETR is set to missing if the denominator is zero or negative and is \\ truncated to the range $[0,1]$. This is then multiplied by -1 . \\ CETR3 \\ Three-year cash effective tax rate: three-year sum of cash tax paid (TXPD) / \\ (three-year sum of pre-tax book income (PI) less special items (SPI)). CETR3 is \\ set to missing if the denominator is zero or negative and is truncated to the range \\ $[0,1]$. This is then multiplied by -1 .
}

CNOL

Change in tax loss carry forward (TLCF) / lagged total assets (AT)

$D D \_B T D$

Desai and Dharmapala (2006) residual book-tax difference from the following firm fixed-effect regression:

MP_BTD ${ }_{i, t}=T_{i, t}+\mu_{i}+\varepsilon_{i, t}$,

where MP_BTD is the Manzon and Plesko book-tax difference; TA is total accruals measured using the cash flow method (Hribar and Collins 2002). Both variables are scaled by lagged total assets (AT) and are winsorized at $1 \%$ and $99 \% ; \mu_{\mathrm{i}}$ is the average value of the residual for firm i over the sample period, and $\varepsilon_{i, t}$ is the deviation of the residual in year $t$ from firm i's average residual. We remove observations with total assets less than $\$ 1$ million (to mitigate small deflator problem) and observations with negative taxable income (TXFED $<0)$.

$D E D$

The quarterly percentage of shares outstanding held by dedicated institutional investors as reported on SEC's Form 13-F filings.

DELTA

Dollar change in CEO wealth (the dollar value of CEO stock and option holdings) associated with a $1 \%$ change in the firm's stock price (in $\$ 000$ s)

DISTANCE $E_{L} \quad$ The relative distance of a Russell 1000 firm to the cutoff firm (the 1,000th firm) each year based on June weights, 0 otherwise.

DISTANCE $_{R} \quad$ The relative distance of a Russell 2000 firm to the cutoff firm (the 1,000th firm) each year based on June weights, 0 otherwise.

EQINC

Equity income (ESUB) / lagged total assets (AT)

ETR

Effective tax rate: Total income tax expense (TXT) / (pre-tax book income (PI) special items (SPI)). ETR is set to missing if the denominator is zero or negative and is truncated to the range $[0,1]$. This is then multiplied by -1 .

ETR3

Three-year effective tax rate: three-year sum of income tax expenses (TXT) / (three-year sum of pre-tax book income (PI) less special items (SPI)). ETR3 is set to missing if the denominator is zero or negative and is truncated to the range [0, 1]. This is then multiplied by -1 . 
EXTXB

FODOM

FORINC

INSTOWN

INTAN

LEV

MARGIN

MBE

MKTCAP

$M P \_B T D$

MTB

NOL

PPE

QIX

ROA

RU2000

$R \& D$

SALEGR
Excess tax benefit of stock options (TXBCO, TXBCFO if after 6/15/2006 when FAS 123 (R) becomes effective) / lagged total assets (AT).

Foreign pre-tax income (PIFO) / total pre-tax income (PI).

Pre-tax foreign income (PIFO) / lagged total assets (AT)

The quarterly percentage of shares outstanding held by institutional investors as reported on SEC's Form 13-F filings.

Intangible assets (INTANG) / lagged total assets (AT)

Long-term debt (DLTT) / lagged total assets (AT)

Net Income (NI) / sales (SALE)

An indicator variable that equals 1 if the reported EPS falls between analyst median consensus forecast and that plus two cents in a fiscal quarter, 0 otherwise.

Market capitalization calculated at the end of May right before the index reconstitution.

Manzon and Plesko (2002) book-tax difference. (U.S. domestic financial income (PIDOM) - U.S. domestic taxable income - State Income Taxes (TXS) - Other Income Taxes (TXO) - Equity in Earnings (ESUB)) / lagged total assets (AT). U.S. domestic taxable income is estimated as the federal tax expense (TXFED) / the statutory maximum corporate tax rate. We remove observations with total assets (AT) less than $\$ 1$ million (to mitigate small deflator problem) and observations with negative taxable income (TXFED $<0)$.

Market value of equity (PRCC_F $\times$ CSHO) / book value of equity (CEQ) at the beginning of year $\mathrm{t}$.

An indicator variable that equals 1 if there is a tax loss carry forward (TLCF > 0) as of the beginning of the year $t, 0$ otherwise

Property, plant, and equipment (PPENT) / lagged total assets (AT)

The quarterly percentage of shares outstanding held by quasi-indexer institutional investors as reported on SEC's Form 13-F filings.

(pre-tax income (PI) - extraordinary items (XI)) / lagged total assets (AT)

An indicator variable that equals 1 if the firm is in the Russell 2000 index, 0 otherwise.

Research and development expense (XRD) / lagged total assets (AT). R\&D is set to 0 when missing.

Sales growth ((SALE/lagged SALE) - 1) 
Selling, general, and administrative expense (XSGA) / lagged total assets (AT). SG\&A is set to 0 when missing.

SHELTER $=-4.86+(5.20 \times \mathrm{BTD})+(4.08 \times \mathrm{DAP})-(1.41 \times \mathrm{LEV})+(0.76 \times$ $\mathrm{SIZE})+(3.51 \times \mathrm{ROA})+(1.72 \times \mathrm{FI})+(2.43 \times \mathrm{R} \& \mathrm{D})$

where BTD is pre-tax book income less estimated taxable income scaled by lagged total assets. Estimated taxable income is current federal tax expense plus current foreign tax expense scaled by 0.35 less change in tax-loss carryforward; DAP is discretionary accruals from the performance-adjusted modified cross-sectional Jones Model; LEV is long-term debt divided by total assets; SIZE is log of total assets; ROA is pre-tax income divided by total assets; FI is an indicator equal to 1 for firms with foreign income, 0 otherwise; $R \& D$ is $R \& D$ expense divided by lagged total assets. The formula is from Wilson (2009).

SIZE

Log $($ PRCC_F $\times$ CSHO) at the beginning of year $\mathrm{t}$.

TRAN

The quarterly percentage of shares outstanding held by transient institutional investors as reported on SEC's Form 13-F filings.

VEGA

Dollar change in CEO wealth (the dollar value of CEO stock and option holdings) associated with a 0.01 change in the standard deviation of the firm's returns (in $\$ 000 \mathrm{~s}$ ) 


\section{Appendix 2: Comparison with Concurrent Papers}

\begin{tabular}{|c|c|c|c|}
\hline & This paper & Chen et al. (2015) & Bird and Karolyi (2016) \\
\hline Sample Period: & $1988-2006$ & $1996-2006$ & $1996-2006$ \\
\hline \multicolumn{4}{|l|}{ Methodology: } \\
\hline Estimation Method & $\begin{array}{l}\text { Non-parametric in main } \\
\text { tests, parametric in } \\
\text { robustness }\end{array}$ & $\begin{array}{l}\text { Parametric in main tests, } \\
\text { two-stage IV in robustness }\end{array}$ & $\begin{array}{l}\text { Two-stage IV in main tests, } \\
\text { non-parametric in } \\
\text { robustness }\end{array}$ \\
\hline Test sample (bandwidth) & $\begin{array}{l}\text { Firms close to Index } \\
\text { threshold (optimal } \\
\text { bandwidth) }\end{array}$ & $\begin{array}{l}\text { Firms around Index } \\
\text { threshold (bandwidth of } \\
500 \text { to 300) }\end{array}$ & $\begin{array}{l}\text { All firms in Russell } 1000 \\
\text { and } 2000 \text { index (no } \\
\text { bandwidth) in main tests }\end{array}$ \\
\hline $\begin{array}{l}\text { Falsification test at pseudo- } \\
\text { thresholds }\end{array}$ & Yes & Yes & Yes \\
\hline Switching sample test & $\begin{array}{l}\text { Yes (switchers close to } \\
\text { threshold only) }\end{array}$ & No & $\begin{array}{l}\text { Yes (all switchers } \\
\text { regardless of distance from } \\
\text { threshold) }\end{array}$ \\
\hline \multicolumn{4}{|l|}{ Results: } \\
\hline GAAP ETR \& Cash ETR & Lower & Lower & Lower \\
\hline Book-tax differences & Higher & Higher & Higher \\
\hline Tax Shelter & More & No Difference & More \\
\hline Net Income Margin & Higher & N/A & N/A \\
\hline $\begin{array}{l}\text { Meet / Beat earnings } \\
\text { forecast }\end{array}$ & Higher & N/A & N/A \\
\hline Tax jurisdiction & N/A & $\begin{array}{l}\text { Lower Federal and State } \\
\text { ETR, but not Foreign ETR }\end{array}$ & Greater foreign tax planning \\
\hline Executive Equity Incentives & $\begin{array}{l}\text { No differential tax } \\
\text { avoidance after controlling } \\
\text { for Delta and Vega in } \\
\text { parametric tests, indicating } \\
\text { equity incentives are } \\
\text { potential mechanisms to } \\
\text { influence managers }\end{array}$ & N/A & $\begin{array}{l}\text { Some effect of equity } \\
\text { incentive pay }\end{array}$ \\
\hline $\begin{array}{l}\text { Governance and information } \\
\text { environment }\end{array}$ & N/A & $\begin{array}{l}\text { Largely unaffected by } \\
\text { governance and } \\
\text { information environment }\end{array}$ & $\begin{array}{l}\text { Some effect of governance } \\
\text { (information environment } \\
\text { unexamined) }\end{array}$ \\
\hline
\end{tabular}


Figure 1

Example to Illustrate Timing of Dependent Variables

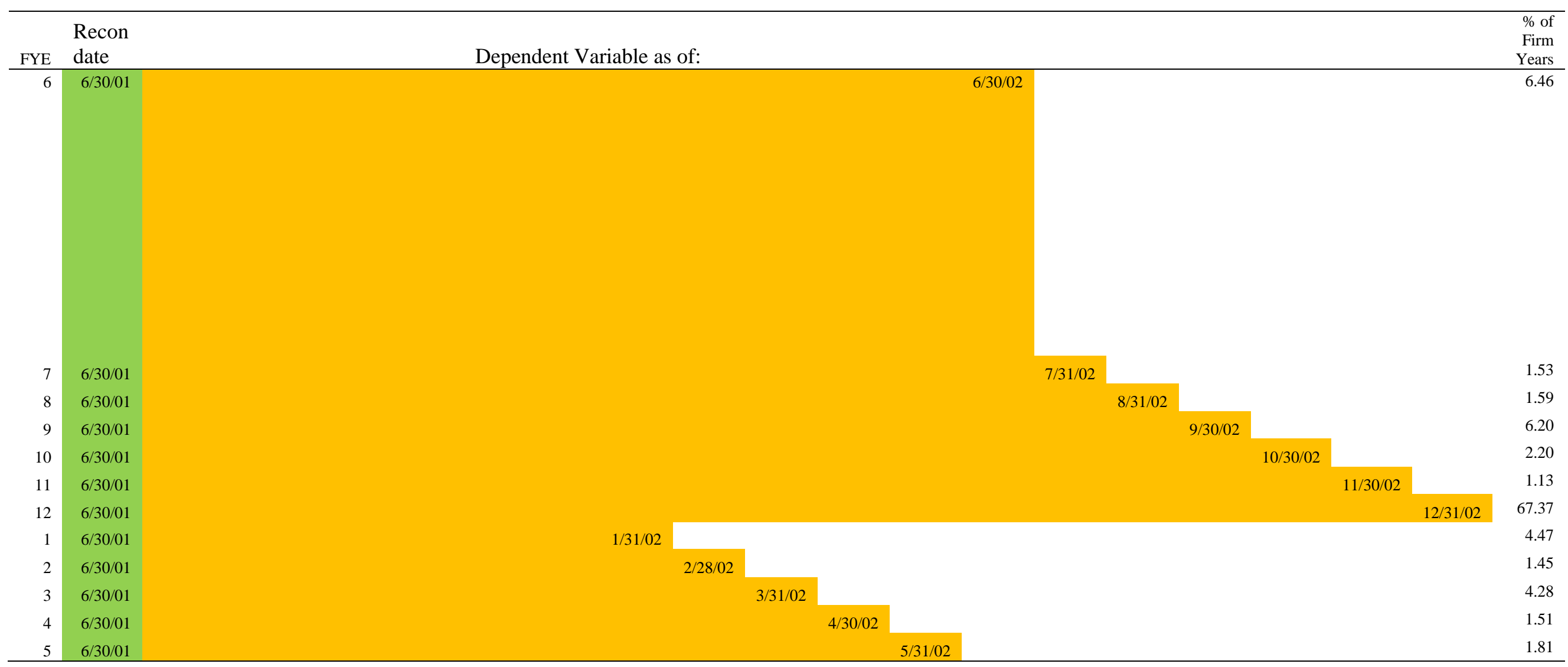

This figure presents an example of the timing of dependent variables following the June index reconstitution. In this example, index reconstitution on June 30, 2001 is used, but the illustration extends to reconstitution in any year. FYE indicates the fiscal year-end month, and \% of firm-years indicates the proportion of the sample consisting of firms with the FYE indicated in the row. For firms with December fiscal year-end for example, the dependent variable is as of December 30, 2002 in this case, and $67.37 \%$ of the sample consists of December fiscal year-end firms. 
Figure 2

\section{Index Weight and Institutional Ownership at the Russell 1000/2000 Threshold}
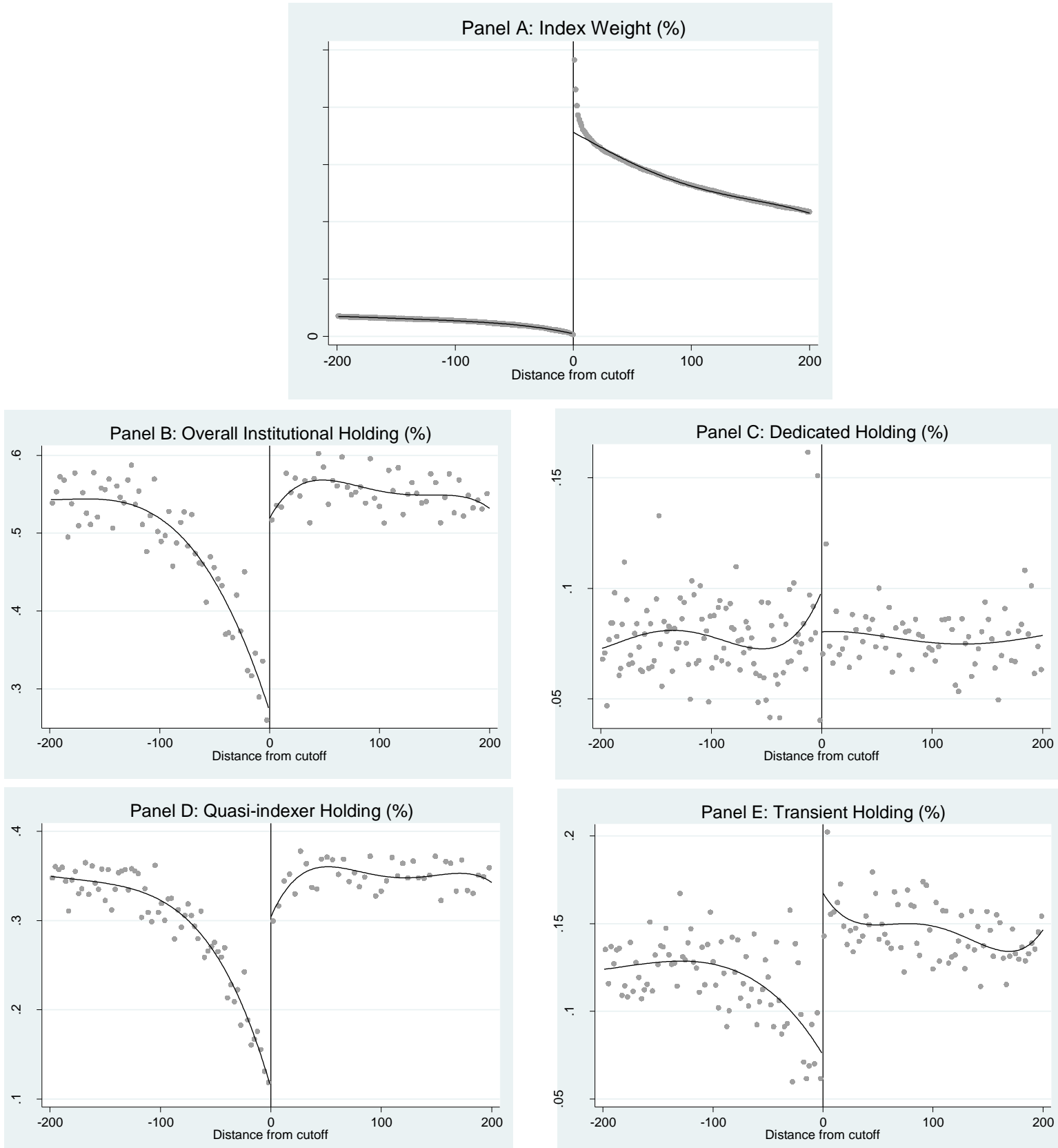

This figure presents graphical analyses of the end-of-June index weight and institutional holdings for firms around the Russell 1000/2000 threshold. The institutional holdings are calculated one quarter after the June index reconstitution. Panel A shows the index weight. Panel B shows the overall institutional holdings (INSTOWN). Panel $\mathrm{C}$ shows the dedicated institutional holdings (DED). Panel D shows the quasi-indexer institutional holdings (QIX). Panel E shows the transient institutional holdings (TRAN). The graphical analysis methodology follows Calonico, Cattaneo, and Titiunik (2015). The horizontal axis is the relative distance of a firm to the Russell 1000/2000 cutoff. The solid black line represents the fourth-order non-parametric local polynomial regression on either side of the cutoff. The dots represent the local sample average within each optimal bin. All variables are defined in Appendix 1. 
Figure 3

\section{Tax Avoidance at the Russell 1000/2000 Threshold}
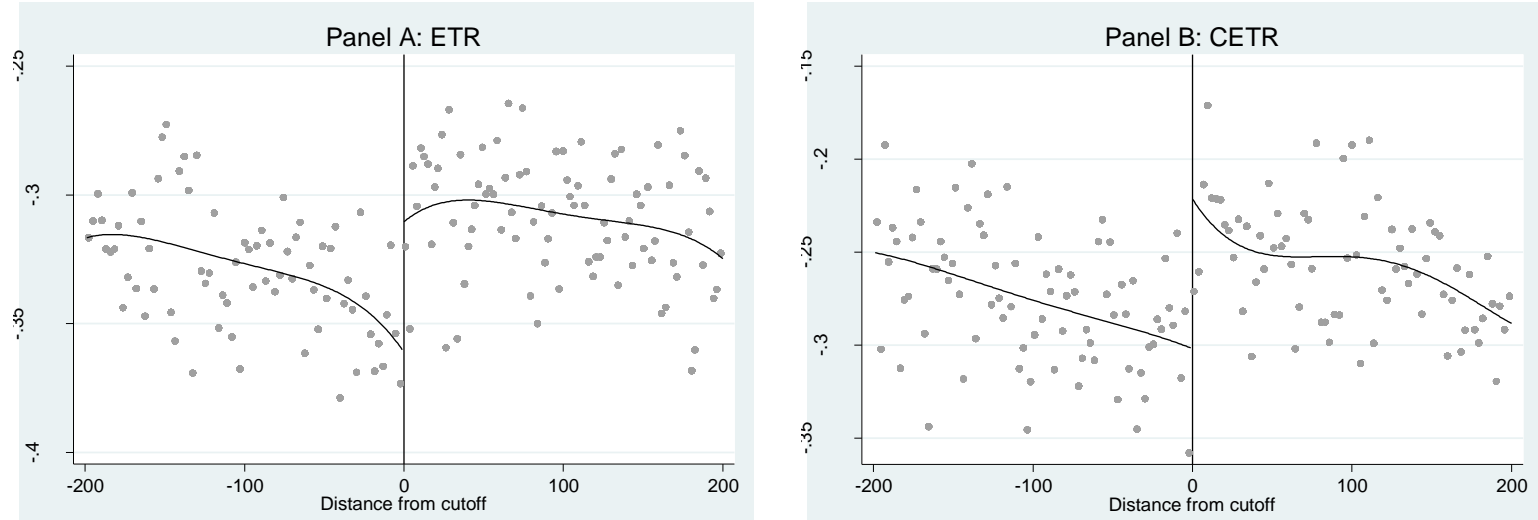

This figure presents graphical analyses of tax avoidance for firms around the Russell 1000/2000 threshold. Panel A shows the ETR measure. Panel B shows the CETR measure. The graphical analysis methodology follows Calonico, Cattaneo, and Titiunik (2015). The horizontal axis is the relative distance of firm to the Russell 1000/2000 cutoff. The solid black line represents the fourth-order non-parametric local polynomial regression on either side of the cutoff. The dots represent the local sample average within each optimal bin. All variables are defined in Appendix 1. 
Table 1

Descriptive Statistics

\begin{tabular}{|c|c|c|c|c|c|c|c|c|c|c|}
\hline & \multicolumn{5}{|c|}{ Russell 1000} & \multicolumn{5}{|c|}{ Russell 2000} \\
\hline & Mean & SD & $\mathrm{P} 25$ & Median & P75 & Mean & $\mathrm{SD}$ & $\mathrm{P} 25$ & Median & P75 \\
\hline ETR & -0.33 & 0.12 & -0.39 & -0.35 & -0.29 & -0.31 & 0.13 & -0.38 & -0.34 & -0.27 \\
\hline CETR & -0.27 & 0.16 & -0.36 & -0.28 & -0.17 & -0.26 & 0.17 & -0.36 & -0.26 & -0.13 \\
\hline ETR3 & -0.32 & 0.12 & -0.38 & -0.34 & -0.28 & -0.30 & 0.13 & -0.38 & -0.34 & -0.26 \\
\hline CETR3 & -0.28 & 0.15 & -0.36 & -0.28 & -0.19 & -0.26 & 0.16 & -0.36 & -0.27 & -0.16 \\
\hline MP_BTD & -0.01 & 0.10 & -0.01 & 0.01 & 0.03 & -0.00 & 0.09 & -0.02 & 0.01 & 0.03 \\
\hline DD_BTD & 0.02 & 0.08 & -0.00 & 0.03 & 0.06 & 0.02 & 0.08 & -0.00 & 0.03 & 0.06 \\
\hline SHELTER & 0.99 & 1.91 & 0.26 & 1.09 & 2.18 & 0.77 & 1.72 & -0.03 & 0.84 & 1.89 \\
\hline MARGIN & -0.00 & 0.55 & 0.02 & 0.06 & 0.11 & -0.01 & 0.59 & 0.02 & 0.06 & 0.12 \\
\hline $\mathrm{MBE}$ & 0.28 & 0.45 & 0.00 & 0.00 & 1.00 & 0.29 & 0.45 & 0.00 & 0.00 & 1.00 \\
\hline INTOWN & 0.48 & 0.25 & 0.29 & 0.48 & 0.67 & 0.55 & 0.24 & 0.37 & 0.57 & 0.75 \\
\hline DED & 0.08 & 0.11 & 0.01 & 0.05 & 0.11 & 0.08 & 0.08 & 0.02 & 0.05 & 0.11 \\
\hline QIX & 0.29 & 0.17 & 0.16 & 0.28 & 0.41 & 0.35 & 0.16 & 0.23 & 0.34 & 0.47 \\
\hline TRAN & 0.12 & 0.11 & 0.04 & 0.09 & 0.17 & 0.15 & 0.12 & 0.05 & 0.12 & 0.21 \\
\hline MKTCAP & 1.31 & 1.02 & 0.52 & 1.15 & 1.77 & 0.82 & 0.49 & 0.34 & 0.81 & 1.19 \\
\hline MTB & 3.10 & 3.71 & 1.42 & 2.18 & 3.55 & 2.88 & 3.18 & 1.45 & 2.08 & 3.20 \\
\hline ROA & 0.08 & 0.15 & 0.02 & 0.07 & 0.15 & 0.08 & 0.14 & 0.02 & 0.07 & 0.14 \\
\hline LEV & 0.24 & 0.26 & 0.03 & 0.18 & 0.35 & 0.25 & 0.25 & 0.03 & 0.21 & 0.36 \\
\hline PPE & 0.33 & 0.28 & 0.10 & 0.26 & 0.50 & 0.33 & 0.29 & 0.09 & 0.26 & 0.50 \\
\hline INTAN & 0.13 & 0.20 & 0.00 & 0.03 & 0.17 & 0.11 & 0.19 & 0.00 & 0.01 & 0.14 \\
\hline NOL & 0.20 & 0.40 & 0.00 & 0.00 & 0.00 & 0.18 & 0.39 & 0.00 & 0.00 & 0.00 \\
\hline CNOL & 0.01 & 0.07 & 0.00 & 0.00 & 0.00 & 0.01 & 0.06 & 0.00 & 0.00 & 0.00 \\
\hline FORINC & 0.01 & 0.02 & 0.00 & 0.00 & 0.01 & 0.01 & 0.03 & 0.00 & 0.00 & 0.00 \\
\hline EQINC & 0.00 & 0.00 & 0.00 & 0.00 & 0.00 & 0.00 & 0.00 & 0.00 & 0.00 & 0.00 \\
\hline R\&D & 0.02 & 0.06 & 0.00 & 0.00 & 0.01 & 0.03 & 0.07 & 0.00 & 0.00 & 0.02 \\
\hline ADVERT & 0.01 & 0.03 & 0.00 & 0.00 & 0.01 & 0.01 & 0.03 & 0.00 & 0.00 & 0.00 \\
\hline SG\&A & 0.21 & 0.24 & 0.02 & 0.12 & 0.33 & 0.21 & 0.24 & 0.01 & 0.13 & 0.32 \\
\hline CAPX & 0.07 & 0.08 & 0.02 & 0.05 & 0.10 & 0.07 & 0.08 & 0.02 & 0.05 & 0.09 \\
\hline SALEGR & 0.15 & 0.31 & 0.01 & 0.10 & 0.21 & 0.17 & 0.31 & 0.02 & 0.11 & 0.24 \\
\hline EXTXB & 0.00 & 0.00 & 0.00 & 0.00 & 0.00 & 0.00 & 0.00 & 0.00 & 0.00 & 0.00 \\
\hline FODOM & 0.09 & 0.33 & 0.00 & 0.00 & 0.06 & 0.10 & 0.34 & 0.00 & 0.00 & 0.03 \\
\hline
\end{tabular}

This table presents descriptive statistics of firms within a bandwidth of 200 around the Russell 1000/2000 cutoff from 1988 to 2006. The descriptive statistics are presented separately for Russell 1000 firms and Russell 2000 firms. All variables are defined in Appendix 1. 
Table 2

\section{Correlation Table}

\begin{tabular}{|c|c|c|c|c|c|c|c|c|c|c|c|c|c|c|c|}
\hline & ETR & CETR & ETR3 & CETR3 & $\begin{array}{l}\mathrm{DD}_{-} \\
\mathrm{BTD}\end{array}$ & $\begin{array}{l}\mathrm{MP}_{-} \\
\mathrm{BTD}\end{array}$ & $\begin{array}{c}\text { SHEL- } \\
\text { TER }\end{array}$ & $\begin{array}{l}\text { MAR- } \\
\text { GIN }\end{array}$ & MBE & $\begin{array}{l}\text { INT- } \\
\text { OWN }\end{array}$ & DED & QIX & TRAN & $\begin{array}{l}\text { MKT- } \\
\text { CAP }\end{array}$ & MTB \\
\hline ETR & & 0.41 & 0.73 & 0.43 & 0.13 & 0.15 & 0.14 & 0.14 & -0.02 & 0.05 & 0.03 & 0.05 & 0.02 & 0.09 & -0.04 \\
\hline CETR & 0.42 & & 0.38 & 0.73 & 0.40 & 0.44 & 0.11 & 0.17 & 0.02 & 0.10 & 0.06 & 0.03 & 0.14 & 0.05 & -0.01 \\
\hline ETR3 & 0.70 & 0.37 & & 0.46 & 0.10 & 0.14 & 0.17 & 0.11 & -0.01 & 0.08 & 0.05 & 0.07 & 0.05 & 0.10 & -0.04 \\
\hline CETR3 & 0.43 & 0.67 & 0.47 & & 0.34 & 0.36 & 0.13 & 0.11 & 0.03 & 0.13 & 0.09 & 0.07 & 0.16 & 0.10 & -0.00 \\
\hline DD_BTD & 0.10 & 0.33 & 0.08 & 0.27 & & 0.81 & 0.29 & 0.45 & 0.04 & 0.13 & 0.04 & 0.17 & 0.04 & 0.15 & -0.01 \\
\hline MP_BTD & 0.10 & 0.30 & 0.09 & 0.23 & 0.94 & & 0.36 & 0.57 & 0.06 & 0.10 & 0.02 & 0.13 & 0.03 & 0.11 & -0.00 \\
\hline SHELTER & 0.04 & 0.10 & 0.08 & 0.10 & 0.64 & 0.72 & & 0.46 & 0.03 & 0.43 & 0.21 & 0.47 & 0.19 & 0.69 & 0.08 \\
\hline MARGIN & 0.15 & 0.15 & 0.11 & 0.11 & 0.66 & 0.69 & 0.54 & & 0.11 & 0.06 & -0.01 & 0.09 & -0.01 & 0.23 & 0.17 \\
\hline MBE & -0.01 & 0.04 & -0.01 & 0.04 & 0.06 & 0.06 & 0.04 & 0.04 & & 0.05 & 0.01 & 0.04 & 0.06 & 0.06 & 0.19 \\
\hline INTOWN & 0.03 & 0.09 & 0.05 & 0.11 & 0.19 & 0.17 & 0.40 & 0.10 & 0.05 & & 0.51 & 0.87 & 0.70 & 0.51 & 0.12 \\
\hline DED & 0.02 & 0.04 & 0.04 & 0.06 & 0.04 & 0.04 & 0.14 & 0.02 & -0.01 & 0.45 & & 0.27 & 0.20 & 0.22 & 0.03 \\
\hline QIX & 0.03 & 0.03 & 0.05 & 0.06 & 0.22 & 0.20 & 0.42 & 0.14 & 0.03 & 0.86 & 0.14 & & 0.45 & 0.51 & 0.05 \\
\hline TRAN & 0.01 & 0.13 & 0.01 & 0.12 & 0.04 & 0.03 & 0.11 & -0.00 & 0.07 & 0.65 & 0.07 & 0.33 & & 0.31 & 0.22 \\
\hline MKTCAP & 0.02 & 0.02 & 0.03 & 0.03 & 0.05 & 0.04 & 0.27 & 0.04 & 0.08 & 0.10 & 0.03 & 0.12 & -0.01 & & 0.24 \\
\hline МТВ & -0.01 & 0.05 & -0.03 & 0.03 & -0.18 & -0.20 & -0.11 & -0.12 & 0.13 & 0.02 & -0.00 & -0.05 & 0.15 & 0.11 & \\
\hline $\mathrm{ROA}$ & -0.20 & -0.06 & -0.17 & -0.11 & 0.74 & 0.82 & 0.68 & 0.60 & 0.13 & 0.18 & 0.01 & 0.18 & 0.10 & 0.07 & 0.01 \\
\hline LEV & 0.10 & 0.15 & 0.10 & 0.17 & 0.06 & 0.03 & -0.02 & 0.01 & -0.08 & 0.05 & 0.04 & 0.02 & 0.05 & -0.03 & -0.04 \\
\hline PPE & -0.10 & 0.05 & -0.10 & 0.07 & 0.24 & 0.16 & 0.10 & 0.08 & -0.07 & -0.01 & -0.03 & -0.00 & -0.03 & -0.00 & -0.04 \\
\hline INTAN & -0.09 & -0.01 & -0.07 & 0.00 & 0.04 & 0.02 & 0.10 & 0.03 & 0.08 & 0.22 & 0.07 & 0.18 & 0.19 & 0.04 & 0.07 \\
\hline NOL & 0.05 & 0.13 & 0.03 & 0.10 & -0.16 & -0.18 & -0.11 & -0.16 & 0.00 & 0.06 & 0.05 & 0.02 & 0.11 & -0.01 & 0.07 \\
\hline CNOL & 0.02 & -0.00 & 0.02 & 0.03 & -0.45 & -0.48 & -0.53 & -0.37 & -0.02 & -0.07 & -0.02 & -0.09 & 0.01 & -0.03 & 0.15 \\
\hline FORINC & 0.03 & 0.03 & 0.04 & 0.02 & 0.05 & 0.07 & 0.37 & 0.09 & 0.05 & 0.18 & 0.06 & 0.17 & 0.09 & 0.16 & 0.10 \\
\hline EQINC & 0.05 & 0.04 & 0.05 & 0.03 & 0.07 & 0.09 & 0.17 & 0.10 & -0.00 & 0.06 & 0.03 & 0.07 & -0.01 & 0.06 & -0.02 \\
\hline $\mathrm{R} \& \mathrm{D}$ & 0.11 & 0.09 & 0.07 & 0.08 & -0.51 & -0.53 & -0.34 & -0.42 & 0.02 & -0.03 & -0.00 & -0.10 & 0.12 & -0.01 & 0.30 \\
\hline ADVERT & -0.08 & -0.08 & -0.08 & -0.09 & -0.01 & -0.00 & 0.00 & 0.03 & 0.04 & -0.01 & -0.01 & -0.01 & 0.03 & 0.03 & 0.10 \\
\hline SG\&A & -0.12 & -0.12 & -0.13 & -0.15 & -0.11 & -0.12 & -0.12 & 0.00 & 0.09 & 0.01 & -0.03 & -0.03 & 0.12 & -0.03 & 0.23 \\
\hline
\end{tabular}




\begin{tabular}{|c|c|c|c|c|c|c|c|c|c|c|c|c|c|c|c|}
\hline CAPX & -0.15 & -0.00 & -0.16 & -0.00 & 0.11 & 0.04 & -0.01 & 0.02 & -0.01 & -0.03 & -0.04 & -0.08 & 0.08 & -0.02 & 0.11 \\
\hline SALEGR & 0.03 & 0.14 & 0.00 & 0.09 & -0.12 & -0.11 & -0.06 & -0.03 & 0.02 & -0.00 & -0.02 & -0.08 & 0.16 & -0.03 & 0.19 \\
\hline EXTXB & -0.02 & 0.06 & -0.01 & 0.03 & 0.07 & 0.06 & 0.11 & 0.05 & 0.06 & 0.20 & 0.04 & 0.18 & 0.21 & 0.02 & 0.10 \\
\hline FORINC & 0.05 & -0.01 & 0.04 & 0.00 & 0.05 & 0.05 & 0.24 & 0.04 & 0.01 & 0.14 & 0.06 & 0.14 & 0.06 & 0.08 & 0.01 \\
\hline
\end{tabular}


Table 2

Correlation Table (Continued)

\begin{tabular}{|c|c|c|c|c|c|c|c|c|c|c|c|c|c|c|c|}
\hline & ROA & LEV & PPE & INTAN & NOL & $\begin{array}{c}\mathrm{C}- \\
\mathrm{NOL}\end{array}$ & $\begin{array}{l}\text { FOR- } \\
\text { INC }\end{array}$ & EQINC & R\&D & $\begin{array}{l}\text { ADV- } \\
\text { ERT }\end{array}$ & SG\&A & CAPX & $\begin{array}{c}\text { SALE- } \\
\text { GR }\end{array}$ & $\begin{array}{c}\text { EXT- } \\
\text { XB } \\
\end{array}$ & $\begin{array}{c}\text { FO- } \\
\text { DOM }\end{array}$ \\
\hline ETR & -0.26 & 0.01 & -0.13 & -0.07 & 0.07 & 0.01 & 0.07 & 0.07 & 0.13 & -0.07 & -0.15 & -0.21 & -0.04 & 0.03 & 0.08 \\
\hline CETR & -0.13 & 0.15 & 0.00 & -0.05 & 0.15 & -0.06 & 0.01 & 0.05 & 0.05 & -0.09 & -0.17 & -0.10 & 0.12 & 0.01 & 0.01 \\
\hline ETR3 & -0.23 & 0.04 & -0.13 & -0.03 & 0.08 & 0.02 & 0.10 & 0.08 & 0.14 & -0.07 & -0.14 & -0.22 & -0.04 & 0.03 & 0.10 \\
\hline CETR3 & -0.18 & 0.17 & 0.02 & -0.02 & 0.13 & -0.01 & 0.02 & 0.05 & 0.05 & -0.11 & -0.20 & -0.09 & 0.06 & -0.00 & 0.02 \\
\hline DD_BTD & 0.39 & 0.12 & 0.29 & 0.01 & -0.10 & -0.20 & 0.02 & 0.05 & -0.20 & -0.03 & -0.10 & 0.17 & 0.03 & 0.06 & 0.03 \\
\hline MP_BTD & 0.46 & 0.10 & 0.18 & -0.02 & -0.12 & -0.23 & 0.02 & 0.06 & -0.21 & -0.05 & -0.11 & 0.07 & 0.09 & 0.05 & 0.01 \\
\hline SHELTER & 0.41 & 0.04 & 0.09 & 0.19 & -0.03 & -0.23 & 0.53 & 0.19 & -0.02 & 0.01 & -0.08 & 0.04 & 0.03 & 0.16 & 0.47 \\
\hline MARGIN & 0.61 & -0.09 & -0.09 & -0.09 & -0.22 & -0.22 & 0.12 & 0.11 & -0.18 & -0.04 & -0.23 & -0.03 & 0.19 & 0.13 & 0.07 \\
\hline MBE & 0.15 & -0.09 & -0.06 & 0.09 & 0.00 & -0.01 & 0.05 & -0.02 & 0.05 & 0.06 & 0.11 & 0.00 & 0.06 & 0.04 & 0.03 \\
\hline INTOWN & 0.18 & 0.07 & 0.02 & 0.27 & 0.06 & -0.02 & 0.22 & 0.09 & 0.06 & 0.01 & 0.06 & -0.02 & 0.04 & 0.25 & 0.20 \\
\hline DED & 0.04 & 0.06 & 0.01 & 0.11 & 0.05 & -0.01 & 0.12 & 0.06 & 0.04 & 0.01 & 0.01 & -0.02 & -0.00 & 0.07 & 0.11 \\
\hline QIX & 0.18 & 0.07 & 0.04 & 0.25 & 0.02 & -0.03 & 0.22 & 0.10 & 0.00 & 0.00 & 0.02 & -0.04 & -0.03 & 0.25 & 0.20 \\
\hline TRAN & 0.14 & 0.03 & 0.00 & 0.21 & 0.11 & 0.01 & 0.12 & 0.02 & 0.14 & 0.04 & 0.13 & 0.07 & 0.17 & 0.21 & 0.11 \\
\hline MKTCAP & 0.16 & 0.09 & 0.05 & 0.21 & -0.02 & -0.02 & 0.22 & 0.13 & -0.02 & 0.01 & -0.14 & 0.01 & -0.01 & 0.17 & 0.20 \\
\hline МТВ & 0.31 & -0.13 & 0.01 & 0.13 & 0.06 & 0.02 & 0.12 & -0.01 & 0.27 & 0.09 & 0.26 & 0.21 & 0.26 & 0.13 & 0.11 \\
\hline ROA & & -0.11 & 0.20 & 0.07 & -0.16 & -0.22 & 0.27 & 0.10 & -0.03 & 0.07 & 0.24 & 0.29 & 0.28 & 0.15 & 0.22 \\
\hline LEV & -0.08 & & 0.40 & 0.12 & 0.01 & 0.00 & -0.01 & 0.10 & -0.25 & -0.06 & -0.21 & 0.10 & 0.05 & -0.09 & -0.01 \\
\hline PPE & 0.12 & 0.38 & & -0.09 & -0.02 & -0.02 & 0.06 & 0.09 & -0.10 & -0.04 & 0.03 & 0.75 & 0.05 & -0.09 & 0.05 \\
\hline INTAN & 0.04 & 0.24 & -0.11 & & 0.13 & 0.02 & 0.18 & 0.02 & 0.07 & 0.10 & 0.19 & -0.07 & 0.07 & 0.19 & 0.17 \\
\hline NOL & -0.20 & 0.03 & -0.05 & 0.12 & & 0.02 & 0.07 & -0.03 & 0.23 & 0.03 & 0.12 & -0.03 & -0.00 & 0.07 & 0.08 \\
\hline CNOL & -0.41 & 0.01 & -0.04 & 0.02 & 0.18 & & -0.05 & -0.03 & 0.10 & 0.01 & 0.02 & -0.02 & -0.03 & -0.03 & -0.04 \\
\hline FORINC & 0.25 & -0.05 & 0.00 & 0.08 & 0.06 & -0.06 & & 0.10 & 0.23 & 0.04 & 0.17 & 0.07 & 0.03 & 0.10 & 0.63 \\
\hline EQINC & 0.13 & 0.04 & 0.06 & -0.00 & -0.04 & -0.07 & 0.07 & & -0.06 & -0.06 & -0.10 & -0.01 & -0.00 & 0.01 & 0.09 \\
\hline $\mathrm{R} \& \mathrm{D}$ & -0.35 & -0.15 & -0.18 & -0.03 & 0.21 & 0.31 & 0.07 & -0.08 & & 0.07 & 0.39 & 0.05 & 0.03 & 0.02 & 0.22 \\
\hline ADVERT & 0.09 & -0.03 & -0.01 & 0.04 & -0.01 & 0.01 & 0.09 & -0.02 & 0.00 & & 0.36 & 0.05 & 0.00 & 0.09 & 0.03 \\
\hline SG\&A & 0.08 & -0.15 & -0.11 & 0.09 & 0.09 & 0.08 & 0.14 & -0.07 & 0.32 & 0.43 & & 0.24 & 0.08 & 0.07 & 0.16 \\
\hline
\end{tabular}




\begin{tabular}{|c|c|c|c|c|c|c|c|c|c|c|c|c|c|c|c|}
\hline CAPX & 0.13 & 0.15 & 0.66 & -0.09 & -0.02 & 0.00 & 0.03 & -0.01 & -0.00 & 0.05 & 0.10 & & 0.18 & -0.07 & 0.06 \\
\hline SALEGR & 0.05 & 0.16 & 0.08 & 0.14 & 0.04 & 0.07 & 0.03 & -0.00 & 0.17 & 0.02 & 0.12 & 0.21 & & 0.07 & 0.01 \\
\hline EXTXB & 0.16 & -0.06 & -0.06 & 0.14 & 0.06 & -0.03 & 0.12 & 0.01 & 0.04 & 0.05 & 0.09 & -0.01 & 0.05 & & 0.09 \\
\hline FORINC & 0.07 & -0.01 & -0.00 & 0.07 & 0.08 & -0.03 & 0.51 & 0.05 & 0.03 & 0.02 & 0.06 & -0.01 & -0.02 & 0.04 & \\
\hline
\end{tabular}

The table presents Pearson (Spearman) correlations below (above) the diagonal for the sample. All variables are defined in Appendix 1. 
Table 3

Institutional Holdings at the Russell 1000/2000 Threshold

\section{Panel A: Differences in Means}

\begin{tabular}{|c|c|c|c|c|c|c|c|c|c|}
\hline & \multicolumn{3}{|c|}{200 Bandwidth } & \multicolumn{3}{|c|}{100 Bandwidth } & \multicolumn{3}{|c|}{50 Bandwidth } \\
\hline & RU1000 & RU2000 & Difference & RU1000 & RU2000 & Difference & RU1000 & RU2000 & Difference \\
\hline INSTOWN & 0.48 & 0.55 & $0.07^{* * *}$ & 0.42 & 0.56 & $0.14^{* * *}$ & 0.36 & 0.56 & $0.20^{* * *}$ \\
\hline \multicolumn{10}{|c|}{ Institutional Holdings by Types } \\
\hline DED & 0.08 & 0.08 & 0.00 & 0.08 & 0.08 & 0.00 & 0.08 & 0.08 & 0.00 \\
\hline QIX & 0.29 & 0.35 & $0.06^{* * *}$ & 0.25 & 0.35 & $0.10^{* * *}$ & 0.20 & 0.35 & $0.15^{* * *}$ \\
\hline TRAN & 0.12 & 0.15 & $0.03^{* * *}$ & 0.11 & 0.15 & $0.05^{* * *}$ & 0.10 & 0.16 & $0.06^{* * *}$ \\
\hline
\end{tabular}

\section{Panel B: Regression Discontinuity Analysis}

\begin{tabular}{lcccc}
\hline & \multirow{2}{*}{ INSTOWN } & \multicolumn{3}{c}{ Institutional Holdings by Types } \\
\cline { 3 - 5 } & & DED & QIX & TRAN \\
\hline RU2000 & $0.259^{* * *}$ & 0.000 & $0.199^{* * *}$ & $0.077^{* * *}$ \\
Z-stat & $(12.26)$ & $(0.00)$ & $(14.87)$ & $(9.54)$ \\
Optimal Bandwidth & Yes & Yes & Yes & Yes \\
\hline
\end{tabular}

This table examines institutional holdings for firms around the Russell 1000/2000 threshold one quarter after the June index reconstitution. Institutional holdings are further decomposed into three types based on the Bushee (2001) classification: quasi-indexer (QIX), dedicated (DED) and transient (TRAN). Panel A shows mean differences in institutional holdings for firms around the Russell 1000/2000 cutoff. Panel B shows estimates of the discontinuity in institutional holdings at the Russell 1000/2000 cutoff. The RD estimation follows Calonico, Cattaneo, and Titiunik (2014) with non-parametric local linear regressions estimated on either side of the cutoff using a triangle kernel and the optimal bandwidth selection algorithm. $\mathrm{z}$ statistics are in parentheses. * ${ }^{* *}$, and ${ }^{* * *}$ indicate significance at two-tailed probability levels of $10 \%, 5 \%$, and 1\%, respectively. RU2000 is an indicator that equals 1 (0) if the firm is in the Russell 2000 (1000). All variables are defined in Appendix 1. 
Table 4

Characteristics of Firms at the Russell 1000/2000 Threshold

Panel A: Differences in Means

\begin{tabular}{|c|c|c|c|c|c|c|c|c|c|}
\hline & \multicolumn{3}{|c|}{200 Bandwidth } & \multicolumn{3}{|c|}{100 Bandwidth } & \multicolumn{3}{|c|}{50 Bandwidth } \\
\hline & RU1000 & RU2000 & Difference & RU1000 & RU2000 & Difference & RU1000 & RU2000 & Difference \\
\hline MKTCAP & 1.31 & 0.82 & $-0.49^{* * *}$ & 1.34 & 0.89 & $-0.45^{* * *}$ & 1.33 & 0.94 & $-0.39^{* * *}$ \\
\hline MTB & 3.04 & 2.97 & -0.07 & 3.25 & 3.19 & -0.06 & 3.02 & 3.23 & -0.21 \\
\hline ROA & 0.10 & 0.08 & $-0.01^{* * *}$ & 0.10 & 0.08 & $-0.02^{* *}$ & 0.09 & 0.09 & -0.00 \\
\hline LEV & 0.28 & 0.27 & -0.01 & 0.30 & 0.27 & -0.03 & 0.34 & 0.30 & -0.04 \\
\hline PPE & 0.41 & 0.36 & -0.05 & 0.39 & 0.36 & -0.03 & 0.42 & 0.37 & -0.05 \\
\hline INTAN & 0.26 & 0.13 & -0.13 & 0.40 & 0.14 & -0.26 & 0.68 & 0.11 & -0.57 \\
\hline NOL & 0.17 & 0.17 & 0.00 & 0.17 & 0.17 & 0.00 & 0.16 & 0.16 & 0.00 \\
\hline CNOL & 0.01 & 0.01 & 0.00 & 0.01 & 0.01 & 0.00 & 0.01 & 0.01 & 0.00 \\
\hline FORINC & 0.01 & 0.01 & 0.00 & 0.01 & 0.01 & 0.00 & 0.01 & 0.01 & $0.00^{*}$ \\
\hline EQINC & 0.00 & 0.00 & 0.00 & 0.00 & 0.00 & 0.00 & 0.00 & 0.00 & 0.00 \\
\hline $\mathrm{R} \& \mathrm{D}$ & 0.08 & 0.08 & -0.00 & 0.09 & 0.09 & -0.00 & 0.11 & 0.09 & -0.02 \\
\hline ADVERT & 0.22 & 0.05 & -0.18 & 0.11 & 0.05 & -0.06 & 0.18 & 0.05 & -0.12 \\
\hline SG\&A & 0.98 & 0.31 & -0.67 & 0.47 & 0.33 & $-0.14^{*}$ & 0.63 & 0.34 & $-0.29^{*}$ \\
\hline CAPX & 0.12 & 0.09 & -0.03 & 0.11 & 0.09 & $-0.02^{* *}$ & 0.13 & 0.10 & -0.03 \\
\hline SALEGR & 0.45 & 0.78 & 0.33 & 0.55 & 0.24 & $-0.31^{* *}$ & 0.83 & 0.26 & $-0.58^{* *}$ \\
\hline EXTXB & 0.00 & 0.00 & -0.00 & 0.00 & 0.00 & -0.00 & 0.00 & 0.00 & -0.00 \\
\hline FODOM & 0.10 & 0.10 & 0.00 & 0.07 & 0.09 & 0.02 & -0.01 & 0.08 & 0.09 \\
\hline
\end{tabular}




\section{Panel B: Regression Discontinuity Analysis}

\begin{tabular}{|c|c|c|c|c|c|c|c|c|c|c|}
\hline & MKTCAP & MTB & ROA & LEV & PPE & INTAN & NOL & CNOL & FORINC & EQINC \\
\hline $\begin{array}{l}\text { RU2000 } \\
\text { Z-stat } \\
\text { Optimal Bandwidth }\end{array}$ & $\begin{array}{c}-0.087 \\
(-0.85) \\
\text { Yes }\end{array}$ & $\begin{array}{c}-0.135 \\
(-0.25) \\
\text { Yes }\end{array}$ & $\begin{array}{c}-0.009 \\
(-0.83) \\
\text { Yes }\end{array}$ & $\begin{array}{c}-0.067 \\
(-0.82) \\
\text { Yes }\end{array}$ & $\begin{array}{l}-0.021 \\
(-0.44) \\
\text { Yes }\end{array}$ & $\begin{array}{l}-0.510 \\
(-1.07) \\
\text { Yes }\end{array}$ & $\begin{array}{c}0.008 \\
(0.47) \\
\text { Yes }\end{array}$ & $\begin{array}{l}-0.005 \\
(-0.50) \\
\text { Yes }\end{array}$ & $\begin{array}{c}0.003 \\
(1.49) \\
\text { Yes }\end{array}$ & $\begin{array}{l}0.000 \\
(0.96) \\
\text { Yes }\end{array}$ \\
\hline & & & ADVERT & SG\&A & & $\mathrm{PX}$ & SALEGR & FODOM & \multicolumn{2}{|c|}{ EXTXB } \\
\hline $\begin{array}{l}\text { RU2000 } \\
\text { Z-stat } \\
\text { Optimal Bandv }\end{array}$ & \multicolumn{2}{|c|}{$\begin{array}{c}-0.025 \\
(-1.57) \\
\text { Yes }\end{array}$} & $\begin{array}{c}-0.129 \\
(-1.27) \\
\text { Yes }\end{array}$ & $\begin{array}{c}-0.692 \\
(-1.52) \\
\text { Yes }\end{array}$ & \multicolumn{2}{|c|}{$\begin{array}{l}-0.035 \\
(-1.21) \\
\text { Yes }\end{array}$} & $\begin{array}{c}-0.995^{*} \\
(-1.91) \\
\text { Yes }\end{array}$ & $\begin{array}{c}0.058 \\
(0.75) \\
\text { Yes } \\
\end{array}$ & \multicolumn{2}{|c|}{$\begin{array}{c}-0.001 \\
(-1.47) \\
\text { Yes }\end{array}$} \\
\hline
\end{tabular}

This table presents the difference in characteristics of firms around the Russell 1000/2000 threshold. Panel A shows mean differences. Panel B shows estimates of the discontinuity in each variable at the Russell 1000/2000 threshold. The RD estimation follows Calonico, Cattaneo, and Titiunik (2014) with non-parametric local linear regressions estimated on either side of the cutoff using a triangle kernel and the optimal bandwidth selection algorithm. $\mathrm{z}$ statistics are in parentheses. ${ }^{*}, * *$, and ${ }^{* * *}$ indicate significance at two-tailed probability levels of $10 \%, 5 \%$, and $1 \%$, respectively. In Panel B, RU2000 is an indicator that equals 1 ( 0 ) if the firm is in the Russell 2000 (1000). All variables are defined in Appendix 1. 
Table 5

Tax Avoidance at the Russell 1000/2000 Threshold

Panel A: Differences in Means

\begin{tabular}{|c|c|c|c|c|c|c|c|c|c|}
\hline & \multicolumn{3}{|c|}{200 Bandwidth } & \multicolumn{3}{|c|}{100 Bandwidth } & \multicolumn{3}{|c|}{50 Bandwidth } \\
\hline & RU1000 & RU2000 & Difference & RU1000 & RU2000 & Difference & RU1000 & RU2000 & Difference \\
\hline ETR & -0.33 & -0.31 & $0.02^{* * * *}$ & -0.34 & -0.30 & $0.03^{* * *}$ & -0.35 & -0.30 & $0.04^{* * * *}$ \\
\hline CETR & -0.27 & -0.26 & $0.02^{* * *}$ & -0.29 & -0.25 & $0.04^{* * *}$ & -0.30 & -0.24 & $0.06^{* * *}$ \\
\hline
\end{tabular}

Panel B: Regression Discontinuity Analysis in Full Sample

\begin{tabular}{lcc}
\hline & $(1)$ & $(2)$ \\
& ETR & CETR \\
\hline RU2000 & $0.051^{* * *}$ & $0.070^{* * *}$ \\
Z-stat & $(6.56)$ & $(5.56)$ \\
Optimal Bandwidth & Yes & Yes \\
\hline
\end{tabular}

Panel C: Regression Discontinuity Analysis in Switching Sample

\begin{tabular}{lcc}
\hline & $(1)$ & $(2)$ \\
& ETR & CETR \\
\hline RU2000 & & \\
Z-stat & $0.064^{* * *}$ & $0.098^{* * *}$ \\
Optimal Bandwidth & $(3.25)$ & $(3.78)$ \\
& Yes & Yes \\
\hline
\end{tabular}




\section{Panel D: Falsification Tests at Other Thresholds}

\begin{tabular}{|c|c|c|c|c|c|c|c|c|}
\hline & \multicolumn{2}{|c|}{ RU500 } & \multicolumn{2}{|c|}{ RU1500 } & \multicolumn{2}{|c|}{ RU2000 } & \multicolumn{2}{|c|}{ RU2500 } \\
\hline & $\begin{array}{c}(1) \\
\text { ETR }\end{array}$ & $\begin{array}{c}(2) \\
\text { CETR } \\
\end{array}$ & $\begin{array}{c}(1) \\
\text { ETR } \\
\end{array}$ & $\begin{array}{c}(2) \\
\text { CETR } \\
\end{array}$ & $\begin{array}{c}(1) \\
\text { ETR } \\
\end{array}$ & $\begin{array}{c}(2) \\
\text { CETR } \\
\end{array}$ & $\begin{array}{c}(1) \\
\text { ETR } \\
\end{array}$ & $\begin{array}{c}(2) \\
\text { CETR } \\
\end{array}$ \\
\hline $\begin{array}{l}\text { Right } \\
\text { Z-stat } \\
\text { Optimal Bandwidth }\end{array}$ & $\begin{array}{r}0.012 \\
(1.38) \\
\text { Yes }\end{array}$ & $\begin{array}{l}0.008 \\
(0.80) \\
\text { Yes }\end{array}$ & $\begin{array}{l}0.000 \\
(0.05) \\
\text { Yes }\end{array}$ & $\begin{array}{c}-0.004 \\
(-0.50) \\
\text { Yes }\end{array}$ & $\begin{array}{c}-0.004 \\
(-0.58) \\
\text { Yes }\end{array}$ & $\begin{array}{c}-0.011 \\
(-0.97) \\
\text { Yes }\end{array}$ & $\begin{array}{c}-0.005 \\
(-0.39) \\
\text { Yes }\end{array}$ & $\begin{array}{c}-0.016 \\
(-1.13) \\
\text { Yes }\end{array}$ \\
\hline
\end{tabular}

This table presents estimates of tax avoidance by firms at the Russell index threshold. Panel A shows mean differences in tax avoidance. Panel B shows estimates of the discontinuity in tax avoidance at the threshold. The RD estimation follows Calonico, Cattaneo, and Titiunik (2014) with non-parametric local linear regressions estimated on either side of the cutoff using a triangle kernel and the optimal bandwidth selection algorithm. Panel $\mathrm{C}$ presents discontinuity estimates from a sample of firms that switch to the Russell 2000 from the Russell 1000. The switching sample includes only switching firms, and compares tax avoidance in the year following the switch to tax avoidance in the year prior to the switch. Panel D shows falsification tests by testing for discontinuities in tax avoidance at pseudo-thresholds. Panel D compares firms on the right ("Right") versus left of the Russell 500, 1500, 2000, and 2500. The dependent variables are two tax avoidance measures, ETR and CETR. z statistics are in parentheses. *, **, and *** indicate significance at two-tailed probability levels of $10 \%, 5 \%$, and $1 \%$, respectively. In Panels B and C, RU2000 is an indicator that equals 1 (0) if the firm is in the Russell 2000 (1000). All variables are defined in Appendix 1. 


\section{Table 6 \\ Tax Shelter Use at the Russell 1000/2000 Threshold}

\begin{tabular}{lc}
\hline & \\
& SHELTER \\
\hline RU2000 & $0.413^{* * *}$ \\
Z-stat & $(3.06)$ \\
Optimal Bandwidth & Yes \\
\hline
\end{tabular}

This table examines discontinuities in tax shelter activities at the Russell index threshold using RD estimation. The dependent variable is SHELTER estimated using the formula in Wilson (2009). RU2000 is an indicator that equals 1 (0) if the firm is in the Russell 2000 (1000). The bias-corrected regression discontinuity (RD) estimation follows Calonico, Cattaneo, and Titiuuik (2014) with non-parametric local linear regressions estimated on either side of the Russell index cutoff using a triangle kernel and the optimal bandwidth selection algorithm. $\mathrm{z}$ statistics are in parentheses. ${ }^{*}, * *$, and ${ }^{* * *}$ indicate significance at two-tailed probability levels of $10 \%, 5 \%$, and $1 \%$, respectively. All variables are defined in Appendix 1. 


\section{Table 7 \\ Net Income Margin at the Russell 1000/2000 Threshold}

\begin{tabular}{lc}
\hline & MARGIN \\
\hline & $0.105^{* * *}$ \\
RU2000 & $(2.77)$ \\
Z-stat & Yes \\
Optimal Bandwidth & \\
\hline
\end{tabular}

This table examines discontinuities in net income margin at the Russell index threshold using RD estimation. The dependent variable is the net income to sale ratio, MARGIN. RU2000 is an indicator that equals $1(0)$ if the firm is in the Russell 2000 (1000). The bias-corrected regression discontinuity (RD) estimation follows Calonico, Cattaneo, and Titiuuik (2014) with non-parametric local linear regressions estimated on either side of the Russell index cutoff using a triangle kernel and the optimal bandwidth selection algorithm. z statistics are in parentheses. ${ }^{*},{ }^{* *}$, and ${ }^{* * *}$ indicate significance at two-tailed probability levels of $10 \%, 5 \%$, and 1\%, respectively. All variables are defined in Appendix 1. 
Table 8

Meeting or Beating Earnings (MBE) Forecasts at the Russell 1000/2000 Threshold

\begin{tabular}{lc}
\hline & MBE \\
\hline RU2000 & $0.079^{* *}$ \\
Z-stat & $(2.49)$ \\
Optimal Bandwidth & Yes \\
\hline
\end{tabular}

This table examines discontinuities in MBE at the Russell index threshold using RD estimation. MBE is an indicator that equals 1 if the firm meets or beats by up to two cents the median of the last forecast of annual earnings made by analysts, and equals 0 otherwise. RU2000 is an indicator that equals 1 (0) if the firm is in the Russell 2000 (1000). The bias-corrected regression discontinuity (RD) estimation follws Calonico, Cattaneo, and Titiuuik (2014) with non-parametric local linear regressions estimated on either side of the Russell index cutoff using a triangle kernel and the optimal bandwidth selection algorithm. $\mathrm{z}$ statistics are in parentheses. ${ }^{*},{ }^{* *}$, and ${ }^{* * *}$ indicate significance at two-tailed probability levels of $10 \%, 5 \%$, and $1 \%$, respectively. All variables are defined in Appendix 1. 